\title{
Effect of soluble calcium and lactose on limiting flux and serum protein removal during skim milk microfiltration ${ }^{1}$
}

\author{
Michael C. Adams, Emily E. Hurt, and David M. Barbano ${ }^{2}$ \\ Northeast Dairy Foods Research Center Department of Food Science, Cornell University, Ithaca, NY 14853
}

\begin{abstract}
The tendency of calcium to promote microfiltration (MF) membrane fouling is well documented, but the role of lactose has not been studied. Milk protein concentrate that is $85 \%$ protein on a dry basis (MPC85) contains less calcium and lactose than skim milk. Our objectives were to determine the effects of skim milk soluble calcium and lactose concentrations on the limiting fluxes (LF) and serum protein (SP) removal factors of $0.1-\mu \mathrm{m}$ ceramic graded permeability membranes. The MF was fed with 3 different milks: skim milk, liquid MPC85 that had been standardized to the protein content of skim milk with reverse osmosis water (MPC), and liquid MPC85 that had been standardized to the protein and lactose contents of skim milk with reverse osmosis water and lactose monohydrate $(\mathrm{MPC}+\mathrm{L})$. Retentate and permeate were continuously recycled to the feed tank. The LF for each feed was determined by increasing flux once per hour from $55 \mathrm{~kg} \cdot \mathrm{m}^{-2} \cdot \mathrm{h}^{-1}$ until flux did not increase with increasing transmembrane pressure. Temperature, pressure drop across the membrane length, and protein concentration in the retentate recirculation loop were maintained at $50^{\circ} \mathrm{C}$, $220 \mathrm{kPa}$, and $8.77 \pm 0.2 \%$, respectively. Experiments were replicated 3 times and the Proc GLM procedure of SAS was used for statistical analysis. An increase in $\mathrm{LF}$ between skim milk $\left(91 \mathrm{~kg} \cdot \mathrm{m}^{-2} \cdot \mathrm{h}^{-1}\right)$ and $\mathrm{MPC}+\mathrm{L}$ $\left(124 \mathrm{~kg} \cdot \mathrm{m}^{-2} \cdot \mathrm{h}^{-1}\right)$ was associated with a reduction in soluble calcium. The $\mathrm{LF}$ of MPC+L was lower than the LF of MPC $\left(137 \mathrm{~kg} \cdot \mathrm{m}^{-2} \cdot \mathrm{h}^{-1}\right)$ due to the higher viscosity contributed by lactose. Permeates produced from the MPC and MPC+L contained more protein than the skim milk permeate due to the transfer of caseins from the micelles into the reduced-calcium sera of the MPC and MPC+L. A SP removal factor was calculated
\end{abstract}

Received February 16, 2015.

Accepted April 26, 2015.

${ }^{1}$ Use of names, names of ingredients, and identification of specific models of equipment is for scientific clarity and does not constitute any endorsement of product by authors, Cornell University, or the Northeast Dairy Foods Research Center.

${ }^{2}$ Corresponding author: dmb37@cornell.edu by dividing true protein in the permeate by SP in the permeate portion of the feed to describe the ease of SP passage through the membrane. No differences in SP removal factors were detected among the 3 feeds below the LF. As the fluxes approached the LF, SP removal factors decreased due to fouling. Feeding a MF system with MPC instead of skim milk will reduce the required membrane surface area, but the permeate protein composition will be slightly higher in casein content.

Key words: microfiltration, limiting flux, serum protein, lactose

\section{INTRODUCTION}

Microfiltration (MF) is a membrane process designed to remove particulate matter $(0.1$ to $10 \mu \mathrm{m})$ from fluids. The dairy industry uses MF for applications such as whey defatting, bacterial cell removal, and protein fractionation of serum proteins $(\mathbf{S P})$ and CN (Karleskind et al., 1995; Elwell and Barbano, 2006; Hurt et al., 2010). In milk, most CN exist as colloidal micelles that are $0.15 \mu \mathrm{m}$ in diameter, on average. Soluble SP are roughly 100 times smaller. Treating skim milk with a $0.1-\mu \mathrm{m}$ MF process should concentrate CN micelles in the retentate and allow SP to pass through the membrane into the permeate. Accumulation of soil on a membrane, or fouling, can limit SP transmission, thus making this separation less efficient. Fouling can also suppress permeate flux and make cleaning more difficult. These effects increase the costs of a MF plant.

Flux and the extent of fouling are dependent on the driving force of the filtration process, transmembrane pressure (TMP). The nature of this dependence can be explained by the critical flux theory (Brans et al., 2004). Briefly, 3 regimes exist wherein the TMP is below, slightly above, and well above a critical pressure, respectively. In the first regime, flux is linearly dependent on TMP according to Darcy's law (Hurt et al., 2015a,b). In the second regime, a critical flux is exceeded, fouling proceeds more rapidly, and flux becomes almost independent of TMP. The apex of this regime is known as the limiting flux $(\mathbf{L F})$, or the maximum stationary flux that can be achieved by increasing TMP (Bacchin et al., 2006). The LF is a result of fouling 
and is dependent on cross-flow velocity, temperature, membrane design, and the feed composition (Samuelsson et al., 1997b). If TMP is increased further, the process enters the third regime and flux begins to decline. Processors should strive to maintain their operations within the second regime to maximize the average flux (Brans et al., 2004).

Because the various solids of milk interact differently with the membrane, the composition of the feed will influence the degree of fouling. Proteins constitute a large proportion of the foulant layer in many dairy filtration processes. Jimenez-Lopez et al. (2008) confirmed the role of $\mathrm{CN}$ micelles in $0.1-\mu \mathrm{m}$ ceramic $\mathrm{MF}$ fouling by microfiltering model fluids composed of micellar CN powder, which had been reconstituted in 3 liquids: water, UF permeate (water plus lactose plus soluble minerals), or MF permeate (water plus lactose plus soluble minerals plus SP). They determined that CN contributed to about $90 \%$ of the resistance of the fouling layer. Although SP were not as detrimental to flux decline, they contributed to the foulant layer as well. These findings were in agreement with those of Zulewska and Barbano (2013), who observed that feeding a polymeric MF system with $\mathrm{CN}$-free skim milk instead of skim milk produced a higher average flux (80 vs. $17 \mathrm{~kg} \cdot \mathrm{m}^{-2} \cdot \mathrm{h}^{-1}$ ) and higher SP removal (59 vs. $35 \%$ reduction) during a continuous $3 \times$ process.

Mineral fouling is considered to be another important cause of flux decline in MF (Vetier et al., 1988). The mineral deposits formed are usually devoid of $\mathrm{Mg}$, $\mathrm{Na}, \mathrm{K}, \mathrm{S}$, and $\mathrm{Cl}$, but $\mathrm{Ca}$ phosphate is always present (Hanemaaijer et al., 1989). Calcium phosphate can precipitate and form scale deposits on and within the membrane. Tan et al. (2014) determined that minerals did not significantly contribute to the fouling structure when microfiltering skim milk at $6^{\circ} \mathrm{C}$ using ceramic membranes. However, increasing process temperature may increase mineral fouling, as $\mathrm{Ca}$ phosphate solubility decreases with increasing temperature (Pouliot et al., 1989). Vetier et al. (1988) noted a substantial increase in mineral fouling after increasing the $\mathrm{MF}$ temperature from 20 to $50^{\circ} \mathrm{C}$ during ceramic $\mathrm{MF}$ of whole milk. The temperature effect is less pronounced above $50^{\circ} \mathrm{C}$. Hurt et al. (2015a) were able to maintain constant flux during a skim milk MF process at temperatures between 50 and $65^{\circ} \mathrm{C}$ without increasing the TMP. Divalent cations such as $\mathrm{Ca}^{2+}$ can also contribute to fouling by facilitating electrostatic protein-protein interactions between the negatively charged carboxyl groups of milk proteins (Rice et al., 2009). Even in the absence of $\mathrm{CN}$ and SP, Ca has been implicated in fouling ceramic MF membranes (Jimenez-Lopez et al., 2008), although contributions of lactose and other nonprotein soluble components have not been experimentally ruled out. Lactose is not thought to be an important foulant in dairy filtration processes (Marshall and Daufin, 1995; Rice et al., 2009). Its role in UF flux suppression is limited to its effect on viscosity (Rao et al., 1994). However, to the best of the authors' knowledge, the effects of lactose on skim milk ceramic MF fouling have not been systematically decoupled from those of other soluble nonprotein milk components.

One method to reduce ceramic membrane fouling due to Ca phosphate might be to feed the MF system with a milk protein concentrate instead of skim milk. A milk protein concentrate is the retentate produced by UF and diafiltration of skim milk and is named according to its percentage of protein on a dry basis (i.e., a milk protein concentrate that is $85 \%$ protein on a dry basis is a MPC85). Relative to skim milk, soluble nonprotein component concentrations (i.e., lactose and soluble minerals) in MPC85 are reduced and protein concentrations are increased. If the ultimate goal of a $\mathrm{MF}$ process is to produce a micellar $\mathrm{CN}$ concentrate (Hurt et al., 2010) with a low lactose content, feeding the system with a MPC85 will decrease the required MF membrane area (Hurt and Barbano, 2015) and may increase the LF by mitigating Ca-induced fouling.

The objectives of this work were to determine the changes in LF and SP removal associated with reductions in lactose and soluble calcium in skim milk during a $0.1-\mu \mathrm{m}$ ceramic graded permeability (GP) membrane MF process at $50^{\circ} \mathrm{C}$. Skim milk, MPC85, and MPC85 with added lactose were each microfiltered while flux was increased from $55 \mathrm{~kg} \cdot \mathrm{m}^{-2} \cdot \mathrm{h}^{-1}$ to the LF. The compositions and viscosities of the feeds, retentates, and permeates from each process were determined and used to explain the results.

\section{MATERIALS AND METHODS}

\section{Experimental Design}

A completely randomized split block design was employed in which feed type was the whole plot factor, flux was the sub plot factor, and replicate was the blocking factor. The experiment was replicated 3 times in different weeks with 3 different batches of fresh pasteurized skim milk and liquid MPC85 (12\% protein, $0.5 \%$ lactose, $0.2 \%$ fat, $14 \%$ total solids) made from that skim milk. Each replicate took place over $4 \mathrm{~d}$ in a week. On the first day, HTST-pasteurized $\left(73^{\circ} \mathrm{C}, 20\right.$ s) skim milk (300 kg) and liquid MPC85 (200 kg) were procured from OATKA Milk Products Cooperative Inc. (Batavia, NY). The second, third, and fourth days were used for MF of the 3 feeds described below. The order of feed MF was randomized within each week and balanced among replicates. 


\section{Feed Preparation}

Three feeds were used in this study: pasteurized skim milk, liquid MPC85 diluted to the protein content of skim milk using reverse osmosis (RO) water (MPC), and liquid MPC85 diluted to the protein content of skim milk with RO water and fortified to the lactose content of skim milk with lactose monohydrate $(\mathbf{M P C}+\mathbf{L}$; 5200 Ultra Refined Natural Lactose, Hilmar Cheese Company Inc., Hilmar, CA). All feeds were refrigerated at $<4^{\circ} \mathrm{C}$ until use. The skim milk required no additional preparation. On the first day of the week, the fat, true protein (TP), and anhydrous lactose concentrations of the skim milk and liquid MPC85 were measured using a mid-infrared (IR) spectrophotometer (Lactoscope FTIR Advanced, Delta Instruments, Drachten, the Netherlands), and an Excel solver program (Microsoft, Redmond, WA) was used to calculate the necessary water and lactose additions for the MPC and MPC $+\mathrm{L}$. On the evenings before the MPC and $\mathrm{MPC}+\mathrm{L} \mathrm{MF}$ runs, these feeds were blended and stored overnight at $<4^{\circ} \mathrm{C}$. When preparing the $\mathrm{MPC}+\mathrm{L}$, lactose was dissolved in the $\mathrm{RO}$ water portion at $50^{\circ} \mathrm{C}$ to facilitate solubilization and then cooled to $<4^{\circ} \mathrm{C}$ by pumping through a plate heat exchanger (model 080-S, AGC Engineering, Manassas, VA) before adding the MPC85. Initial solver calculations were based on the IR analysis of the liquid MPC85. Lactose (when necessary) and about $85 \%$ of the calculated RO water addition were added to the liquid MPC85 based on the MPC85 IR measurement. The composition of the initial diluted feed was then measured by IR again and a final addition of RO water was made based on these results to avoid over dilution. On the day of use, each feed was heated to $50^{\circ} \mathrm{C}$ by pumping through a plate heat exchanger (model 080-S) at $60^{\circ} \mathrm{C}$ into a $379-\mathrm{L}$ jacketed vat. Feeds were held at $50^{\circ} \mathrm{C}$ in the vat for 15 min before sending product to the MF system.

\section{Microfiltration Operation}

On the evening before processing, the pilot-scale MF system (Tetra Alcross M7, TetraPak Filtration Systems, Aarhus, Denmark) was cleaned as described by Zulewska et al., (2009). Briefly, the nitric acid storage solution $(0.55 \% \mathrm{vol} / \mathrm{vol})$ was flushed out of the system using $25^{\circ} \mathrm{C} \mathrm{RO}$ water until the flush water was neutral (15 min). The MF system was gradually heated $\left(<10^{\circ} \mathrm{C} / \mathrm{min}\right)$ to $80^{\circ} \mathrm{C}$ using $85^{\circ} \mathrm{C} \mathrm{RO}$ water, Ultrasil 25 (Ecolab Inc., St. Paul, MN) was added to the system $(1.95 \% \mathrm{vol} / \mathrm{vol})$, and the Ultrasil caustic solution was recirculated for $30 \mathrm{~min}$ with the feed and retentate recirculation pumps on. After cleaning, the system was gradually cooled $\left(<10^{\circ} \mathrm{C} / \mathrm{min}\right)$ to $50^{\circ} \mathrm{C}$ and the caustic solution was flushed out of the system using $25^{\circ} \mathrm{C} \mathrm{RO}$ water until the flush water was neutral (15 min).

The system was equipped with 0.1- $\mu \mathrm{m}$ Membralox GP membranes (EP1940, Pall Corp., East Hills, NY). The system's stainless steel membrane module housed 7 ceramic $\alpha$-alumina elements, each with 19 circular channels that were $4 \mathrm{~mm}$ in diameter and $1.02 \mathrm{~m}$ in length for a total membrane surface area of $1.68 \mathrm{~m}^{2}$. With the exception of the GP membrane module, the MF system was identical to the one described by Adams and Barbano (2013). Pressure gauges were mounted on the system to monitor retentate pressure at the membrane inlet $\left(\mathbf{P}_{\mathbf{R i}}\right)$, retentate pressure at the membrane outlet $\left(\mathbf{P}_{\mathbf{R o}}\right)$, and permeate pressure at the membrane inlet $\left(\mathbf{P}_{\mathbf{P i}_{\mathbf{i}}}\right)$. Because no pressure gauge was present at the permeate outlet port, permeate pressure at the membrane outlet $\left(\mathbf{P}_{\mathbf{P o}_{\mathbf{o}}}\right)$ was calculated as $\mathrm{P}_{\mathrm{Pi}}$ plus $13.79 \mathrm{kPa}$ based on the height and density of the vertical column of liquid.

On the morning of processing, the MF system was flushed with $50^{\circ} \mathrm{C} \mathrm{RO}$ water to heat the system and remove the storage acid. A clean membrane water flux was measured using $50^{\circ} \mathrm{C} \mathrm{RO}$ water and pressure gauges were corrected to account for their vertical heights so that accurate TMP at the inlet and outlet and average TMP $\left(\mathrm{TMP}_{\mathrm{i}}, \mathrm{TMP}_{\mathrm{o}}\right.$, and $\mathrm{TMP}_{\mathrm{avg}}$, respectively) could be calculated (Adams and Barbano, 2013). Initial MF processing conditions were then set on RO water. To do this, the retentate recirculation pump was turned on and controlled using a variable frequency drive (MC Series, model M12100C, Lenze AC Tech, Uxbridge, MA) to achieve a $220-\mathrm{kPa}$ pressure drop along the length of the membrane $\left(\boldsymbol{\Delta} \mathbf{P}=\mathrm{P}_{\mathrm{Ri}}-\mathrm{P}_{\mathrm{Ro}}\right)$. The permeate valve was then opened to achieve a flux of $55 \mathrm{~kg} \cdot \mathrm{m}^{-2} \cdot \mathrm{h}^{-1}$ and the retentate valve was opened to achieve a concentration factor $(\mathbf{C F})$ of $2.94 \times$. The system feed source was then switched from $50^{\circ} \mathrm{C}$ RO water to $50^{\circ} \mathrm{C}$ feed $(300$ $\mathrm{kg}$ ) and the RO water was flushed out of the system. Permeate and retentate were collected into standard 38-L milk cans, weighed, and then discarded while flushing. In total, $175 \mathrm{~kg}$ of permeate, retentate, and $\mathrm{RO}$ water was collected to bring the protein concentration in the retentate recirculation loop to the target $8.5 \%$, as determined by IR. Once the water had been flushed from the system, the retentate and permeate were recycled back to the feed vat and the remainder of the experiment was conducted in total recycle. The system was allowed to reach a steady retentate protein concentration ( $8.5 \%$ as determined by IR) while in recycle. Once stable, a flux-stepping method similar to the ones described by Samuelsson et al. (1997a) and Bacchin et al. (2006) was employed to determine the LF. Flux was increased by 10 to $20 \mathrm{~kg} \cdot \mathrm{m}^{-2} \cdot \mathrm{h}^{-1}$ each 
Table 1. Mean $(\mathrm{n}=3)$ fluxes $\left(\mathrm{kg} \cdot \mathrm{m}^{-2} \cdot \mathrm{h}^{-1}\right)$ at each flux step ${ }^{1}$ for skim milk, milk protein concentrate (MPC), and MPC with added lactose $(\mathrm{MPC}+\mathrm{L})$

\begin{tabular}{lcrc}
\hline Step & Skim & MPC & MPC+L \\
\hline 1 & 55.2 & 55.0 & 54.8 \\
2 & 65.7 & 75.7 & 75.0 \\
3 & 77.0 & 96.4 & 96.7 \\
4 & 86.0 & 117.3 & 119.1 \\
5 & 90.8 & 137.1 & 124.2 \\
\hline
\end{tabular}

${ }^{1}$ Flux was increased once per $\mathrm{h}$ according to the values above.

hour (Table 1), with the first hour remaining at 55 $\mathrm{kg} \cdot \mathrm{m}^{-2} \cdot \mathrm{h}^{-1}$, until a $\mathrm{LF}$ was reached.

During the flux-stepping procedure, permeate mass flux and CF were measured every 15 min by collecting retentate and permeate from the system into 2 tared 19-L buckets. After 2 min of collection, the buckets were weighed and the CF was calculated. Samples of permeate and retentate were collected and analyzed by IR to monitor the composition every 15 min. After 45 min at each flux, the retentate and permeate were collected continuously for $15 \mathrm{~min}$ and samples for analytical testing were collected. The permeate and retentate that remained after sampling were added back to the feed vat and the flux was increased. A LF was reached when flux could no longer be increased by increasing TMP. At this point, a fouled water flux was determined with $50^{\circ} \mathrm{C} \mathrm{RO}$ water and the MF system was cleaned as described by Zulewska et al. (2009).

\section{Processing Calculations}

Resistances. Resistances were calculated according to Darcy's law (equation 1), where $\mathrm{R}$ is the resistance $\left(\mathrm{m}^{-1}\right), \mu$ is the permeate viscosity $(\mathrm{Pa} \cdot \mathrm{s})$, and TMP and flux are in units of $\mathrm{Pa}$ and $\mathrm{m}^{3} \cdot \mathrm{m}^{-2} \cdot \mathrm{s}^{-1}$, respectively.

$$
\mathrm{R}=\frac{\mathrm{TMP}}{\mu \times \text { Flux }}
$$

The resistance of the clean membrane $\left(\mathbf{R}_{\mathrm{M}}\right)$ was calculated at each flux used in this study by measuring TMP while the system was operated on $50^{\circ} \mathrm{C} \mathrm{RO}$ water with the feed pump and retentate recirculation pump running. The viscosity of water at $50^{\circ} \mathrm{C}(0.547 \mathrm{mPa} \cdot \mathrm{s})$ was used for this calculation. The combined resistance of the concentration polarization gel layer and fouling layer $\left(\mathbf{R}_{\mathbf{C P}+\mathbf{F}}\right)$ was calculated by subtracting the clean membrane resistance from the total resistance calculated during processing. The viscosities of the different MF permeates were used for the combined resistance calculations. Fouling ratios were calculated by dividing $\mathrm{R}_{\mathrm{CP}+\mathrm{F}}$ by $\mathrm{R}_{\mathrm{M}}$.
Reynolds Numbers. The dimensionless Reynolds number (Re) indicates whether flow is turbulent $(>4,000)$ or laminar $(<2,100)$. Reynolds numbers were calculated for the retentates at each flux step according to equation 2 , where $\rho$ is the retentate density at $50^{\circ} \mathrm{C}\left(\mathrm{kg} \cdot \mathrm{m}^{-3}\right), \mathrm{D}$ is the membrane channel diameter $(0.004 \mathrm{~m}), \mathrm{V}$ is the average retentate cross-flow velocity $\left(\mathrm{m} \cdot \mathrm{s}^{-1}\right)$, and $\mu$ is the retentate viscosity at $50^{\circ} \mathrm{C}(\mathrm{Pa} \cdot \mathrm{s})$.

$$
\operatorname{Re}=\frac{\rho \mathrm{DV}}{\mu}
$$

\section{Ultracentrifugation}

Feed samples were ultracentrifuged at the end of each replicate to separate the $\mathrm{CN}$ micelles from the serum phase so that soluble $\mathrm{Ca}$ and soluble proteins could be measured by analysis of the supernatants. Approximately $120 \mathrm{~g}$ of feed was divided among 12 screwcapped, polycarbonate centrifuge tubes (UltraBottle 3430-1610, Nalge Company, Rochester, NY) and centrifuged at 100,000 $\times g$ for 60 min (Sauer and Moraru, 2012) at $40^{\circ} \mathrm{C}$ using a Beckman L8-70M Ultracentrifuge (Beckman-Coulter Inc., Brea, CA) and a titanium rotor (50 Ti, Beckman-Coulter Inc.). The clear supernatants from all tubes were carefully collected using a $10-\mathrm{mL}$ syringe (Luer-Lock, Thermo-Scientific, Waltham, MA) with a $76-\mathrm{mm}$ needle and pooled. Supernatants were frozen at $-80^{\circ} \mathrm{C}$ until analysis.

\section{Analytical Testing}

Proximate Analyses. Feed samples were collected before processing. Retentate and permeate samples were collected during processing and analyzed using a calibration for milk to rapidly estimate fat, anhydrous lactose, and TP using IR (Kaylegian et al., 2006). The IR analysis was done to confirm that the retentate protein concentration remained near $8.5 \%$ during processing and to detect changes in SP passage in the permeate during a processing run. Feed TS, fat, anhydrous lactose, total nitrogen (TN), NPN, and noncasein nitrogen (NCN) were determined using forcedair oven drying (AOAC International, 2000; method 990.20; 33.2.44), ether extraction (AOAC International, 2000; method 989.05 ; 33.2.26), enzymatic anhydrous lactose method (Lynch et al., 2007, method 2006.06), Kjeldahl (AOAC International, 2000; method 991.20; 33.2.11), Kjeldahl (AOAC International, 2000; method 991.21; 33.2.12), and Kjeldahl (AOAC International, 2000; method 998.05; 33.2.64), respectively. Feed NCN preparation was modified by increasing the amounts of sodium acetate $(1 \mathrm{~N})$ and acetic acid $(10 \% \mathrm{vol} / \mathrm{vol})$ from $1 \mathrm{~mL}$ each to $5.5 \mathrm{~mL}$ each to fully precipitate $\mathrm{CN}$ 
(Wojciechowski and Barbano, 2015). Crude protein was calculated by multiplying TN by 6.38 , TP was calculated by subtracting NPN from TN and multiplying by 6.38, CN was calculated by subtracting NCN from TN and multiplying by 6.38 , and SP content was calculated by subtracting NPN from NCN and multiplying by 6.38 . Permeate and retentate samples from each flux step were analyzed for TS, TN, and NPN using the same methods as the feed samples and TP was calculated. Retentate NCN was measured using the modified NCN method described above (Wojciechowski and Barbano, 2015) and $\mathrm{CN}$ was calculated. The $\mathrm{pH}$ of the feeds, permeates, and retentates was measured during processing with a solid polymer electrode (HA405-DXK-S8/120, Mettler-Toledo, Bedford, MA) and an Accumet 915 $\mathrm{pH}$ meter (Fisher Scientific, Pittsburgh, PA) that was calibrated at $50^{\circ} \mathrm{C}$ using standard $\mathrm{pH} 4$ and 7 buffer solutions (SB101, SB107, Fisher Scientific). All feed, permeate, and retentate TN, NPN, and NCN samples were immediately refrigerated at $<4^{\circ} \mathrm{C}$ and analyzed within $24 \mathrm{~h}$ of processing. All feed, permeate, and retentate TS, fat, and anhydrous lactose samples were immediately frozen at $-80^{\circ} \mathrm{C}$ until analysis.

Calcium Analysis. Permeate, feed, and ultracentrifugation supernatant $\mathrm{Ca}$ contents were determined by inductively coupled mass spectrometry. The procedure described by Sauer and Moraru (2012) was used and modified with the addition of $1 \mathrm{~mL}$ of $\mathrm{H}_{2} \mathrm{O}_{2}$ to the digestion solution. For the feeds, total Ca was taken to be the Ca measured in the feed sample and soluble Ca in the permeate portion of the feed was taken to be the Ca measured in the ultracentrifugation supernatant of the feed sample.

Soluble Protein Analysis. Proteins in the ultracentrifugation supernatants and MF permeates were identified by reducing SDS-PAGE at Daisy Brand (Garland, TX). A microfluidic chip-based capillary electrophoresis system (Experion Automated Electrophoresis Station, Bio-Rad Laboratories Inc., Hercules, CA) and protein testing kit (Experion Pro260 Analysis Kit, Bio-Rad Laboratories Inc.) were used to determine the relative quantities of $\alpha_{\mathrm{s} 1}-\mathrm{CN}, \beta-\mathrm{CN}, \alpha_{\mathrm{s} 2}+\kappa-\mathrm{CN}$, $\alpha-\mathrm{LA}, \beta-\mathrm{LG}, \mathrm{BSA}$, and lactoferrin. Between 85 and $90 \%$ of the total peak area in each electropherogram was accounted for by the sum of these 7 protein fractions. All reagents were supplied by Bio-Rad Laboratories Inc. and included in the Pro 260 Analysis Kit, unless otherwise noted.

The Pro260 gel and fluorescent gel stain were prepared according to the manufacturer's instructions. The reducing buffer was prepared by combining 30 $\mu \mathrm{L}$ of the ProP260 kit sample buffer with $1 \mu \mathrm{L}$ of $\beta$-mercaptoethanol. The buffer contains lithium dodecyl sulfate, which binds to the proteins. The fluorescent gel stain, in turn, binds to the lithium dodecyl sulfate, fluoresces in proportion to the amount of protein present, and is detected by the Experion system. Each sample was diluted with deionized water to a TP concentration of $0.09 \%$ wt/wt, based on Kjeldahl data, then $4 \mu \mathrm{L}$ of the diluted sample and $2 \mu \mathrm{L}$ of the reducing buffer were combined in a 0.25 - $\mathrm{mL}$ snap-cap microcentrifuge tube (Fisher Scientific). In addition, a ladder sample containing marker proteins of known molecular weights was prepared in the same manner by combining $4 \mu \mathrm{L}$ of the Pro260 kit ladder and $2 \mu \mathrm{L}$ of reducing buffer. The sample-buffer and ladder-buffer mixtures were centrifuged briefly at $2,000 \times g$ for $30 \mathrm{~s}$ at $25^{\circ} \mathrm{C}$ (Mini Centrifuge, Bio-Rad Laboratories Inc.) to collect the liquid in the bottom of the tubes and the tubes were placed in a boiling water bath for 5 min. The condensates in the tubes were then centrifuged down again and the samples and ladder were further diluted by adding $84 \mu \mathrm{L}$ of deionized water to each tube. Each microfluidic chip, analogous to a gel slab, was loaded with a prepared ladder for molecular weight comparisons, 9 prepared samples, and a prepared skim milk sample to run as a check for consistency of analysis from chip to chip. Each sample was analyzed in duplicate from a common tube. The area under the peak corresponding to each protein fraction was calculated using Experion Software (version 3.20, Bio-Rad Laboratories Inc.) by manually assigning peaks and using a straight baseline integration approach.

\section{Serum Protein Removal Calculations}

The SP removal factor for each flux step were estimated using Kjeldahl data of the feeds and permeates. Based on previous work (Hurt et al., 2010, 2015a), all permeate TP was assumed to be SP. The SP removal factor was calculated by dividing the permeate TP by the feed $\mathrm{SP}$ in the permeate portion of the feed $\left[\mathrm{SP}_{\mathrm{Feed}} /\right.$ $\left.\left(100-\mathrm{CN}_{\text {Feed }}\right) \times 100\right]$.

\section{Apparent Viscosity and Density Measurements}

Apparent viscosities of all feeds and retentates were measured using a rotational viscometer (LV-DV2T, Brookfield Engineering Laboratories Inc., Middleboro, MA) equipped with a jacketed cup and bob fixture (Enhanced UL Adapter, Brookfield Engineering Laboratories Inc.). All samples were measured at $50 \pm 1^{\circ} \mathrm{C}$ at a constant shear rate of $73 \mathrm{~s}^{-1}$. Temperature was maintained by placing $16 \mathrm{~mL}$ of tempered sample into the cup and circulating $50^{\circ} \mathrm{C}$ water through the jacket during measurement. Each sample measurement reflected the average viscosity obtained under $30 \mathrm{~s}$ of shear after a 20 -s shear equilibration period. 
Permeate viscosities at $50^{\circ} \mathrm{C}$ were below the sensitivity of the viscometer $(<0.80 \mathrm{mPa} \cdot \mathrm{s})$. To overcome this limitation, equal amounts of permeate from all flux steps within a day were pooled and measured at temperatures between 2 and $40^{\circ} \mathrm{C}$, an Arrhenius plot was constructed, and the least squares parameters for the Arrhenius equation (equation 3) were derived using linear regression (Microsoft Excel):

$$
\mu=A e^{\frac{E}{R T}} .
$$

In equation $3, \mu$ is the permeate viscosity $(\mathrm{Pa} \cdot \mathrm{s}), \mathrm{A}$ is the pre-exponential constant $(\mathrm{Pa} \cdot \mathrm{s}), \mathrm{E}$ is the activation energy required for flow $\left(\mathrm{J} \cdot \mathrm{mol}^{-1}\right), \mathrm{R}$ is the universal gas constant $\left(8.314 \mathrm{~J} \cdot \mathrm{K}^{-1} \cdot \mathrm{mol}^{-1}\right)$, and $\mathrm{T}$ is the absolute temperature $(\mathrm{K})$. The equation that minimized the least squares $\left(\mathrm{R}^{2}>0.995\right)$ was used to estimate permeate viscosity at $50^{\circ} \mathrm{C}$ for each day of processing.

Retentate densities were determined at $50^{\circ} \mathrm{C}$ with a pycnometer (Weissberger and Rossiter, 1971). The density of distilled water was measured at $50^{\circ} \mathrm{C}$ using the same technique to verify the accuracy of the method.

\section{Statistical Analysis}

Type III SS were analyzed by ANOVA using the Proc GLM procedure of SAS (SAS version 9.4, SAS Institute Inc., Cary, NC). To detect differences $(P<$ 0.05) in composition among feeds, the general linear model $(\mathbf{G L M})$ was dependent variable $=$ feed + replicate + error, where replicate was considered a random variable. To detect differences $(P<0.05)$ in processing variables, retentates, and permeates among feeds and fluxes, the GLM was dependent variable $=$ feed + flux + replicate + feed $\times$ flux + replicate $\times$ feed + error, where replicate and replicate $\times$ feed were random variables. Because feed was a whole plot factor in the split block design, its significance was tested using replicate $\times$ feed as the error term. For comparisons of least squares means among the feeds and fluxes, a Tukey-Kramer adjustment was made for multiple comparisons.

\section{RESULTS AND DISCUSSION}

\section{Proximate Compositions of Feeds, Retentates, and Permeates}

Feed Compositions. The amounts of RO water and lactose monohydrate added during $\mathrm{MPC}$ and $\mathrm{MPC}+\mathrm{L}$ preparation were based on IR determinations of the MPC85 lactose and TP concentrations. Because the IR was calibrated for testing normal milk in the range of 2 to $4.3 \%$ TP, the intercorrection factors (Lynch et al., 2006) for fat on protein (0.061) and lactose on protein (0.045) may not apply when testing diluted MPC85, MF retentate, and MF permeate. The IR underestimated MPC and MPC+L TP and lactose by about $5 \%$. Consequently, both the $\mathrm{MPC}$ and $\mathrm{MPC}+\mathrm{L}$ were underdiluted with $\mathrm{RO}$ water. In the present study and in previous work (Hurt et al., 2015a), the removal of the soluble minerals, lactose, and NPN increased the relative concentration of water in the milk and this may have caused slightly different intercorrection factors to be needed when testing these types of filtration samples. The underdilution caused some minor variations among the 3 feed compositions (Table 2). A goal of the design of this experiment was to produce feeds with the same TP concentrations. However, the $\mathrm{MPC}+\mathrm{L}$ had more TP and CN than MPC $(P<0.05)$ and MPC had more TP and $\mathrm{CN}$ than the skim milk $(P<0.05)$ based on Kjeldahl analysis (Table 2). No differences $(P>$ 0.05 ) were detected in $\mathrm{SP}$ or $\mathrm{CN}$ as a percentage of TP among the 3 feeds. Another goal of the design of this experiment was to produce a MPC $+\mathrm{L}$ with the same lactose content as that of the skim milk. Underdilution also caused MPC $+\mathrm{L}$ lactose to be higher $(P<0.05)$ than skim lactose, although MPC lactose was still lower $(P<0.05)$ than both skim and MPC + L lactose. Skim milk fat was lower $(P<0.05)$ than that of $\mathrm{MPC}+\mathrm{L}$, although this was not considered important because all feeds contained $<0.06 \%$ fat and the differences were small. The addition of lactose to the MPC+L increased its TS relative to that of the MPC $(P<0.05)$. Skim milk TS was higher $(P<0.05)$ than $\mathrm{MPC}+\mathrm{L}$ TS as a result of the reduction in MPC85 soluble minerals and NPN during UF. Skim milk NPN and NCN were higher $(P<0.05)$ than those of MPC and MPC $+\mathrm{L}$ for the same reasons. The $\mathrm{pH}$ of the feeds was not adjusted before MF because this would most likely not be done in a production environment. The UF diafiltration process and addition of RO water to the MPC and MPC+L diluted hydrogen ions and buffering salts, thereby increasing $(P<0.05)$ their $\mathrm{pH}$ relative to that of the skim milk.

Retentate Composition. Skim milk retentate TS were higher $(P<0.05)$ than $\mathrm{MPC}+\mathrm{L}$ retentate TS due to differences in NPN and mineral contents and MPC+L TS were higher $(P<0.05)$ than MPC TS due to a difference in lactose content (Table 3 ). Because no differences $(P>0.05)$ in $\mathrm{CF}$ were detected among the 3 feeds (data not shown), the underdilution of the MPC and $\mathrm{MPC}+\mathrm{L}$ resulted in $\mathrm{CP}$ and $\mathrm{TP}$ values that were higher $(P<0.05)$ than those of skim milk. Differences $(P<0.05)$ in retentate NPN were consistent with those 
Table 2. Mean $(\mathrm{n}=3)$ compositions of skim milk, milk protein concentrate (MPC), and MPC with added lactose $(\mathrm{MPC}+\mathrm{L})$ used to feed the $0.1-\mu \mathrm{m}$ microfiltration process

\begin{tabular}{|c|c|c|c|c|c|}
\hline Item & Skim & $\mathrm{MPC}$ & $\mathrm{MPC}+\mathrm{L}$ & $\mathrm{SE}$ & $\mathrm{R}^{2}$ \\
\hline TS (\%) & $9.255^{\mathrm{a}}$ & $3.912^{\mathrm{c}}$ & $8.833^{\mathrm{b}}$ & 0.048 & $>0.99$ \\
\hline $\mathrm{CP}(\%)$ & $3.414^{\mathrm{ab}}$ & $3.382^{\mathrm{b}}$ & $3.458^{\mathrm{a}}$ & 0.023 & 0.85 \\
\hline Nonprotein N $\times 6.38(\%)$ & $0.184^{\mathrm{a}}$ & $0.029^{\mathrm{b}}$ & $0.028^{\mathrm{b}}$ & 0.004 & $>0.99$ \\
\hline Noncasein $\mathrm{N} \times 6.38(\%)$ & $0.756^{\mathrm{a}}$ & $0.607^{\mathrm{b}}$ & $0.621^{\mathrm{b}}$ & 0.016 & 0.98 \\
\hline True protein (\%) & $3.230^{\mathrm{c}}$ & $3.353^{\mathrm{b}}$ & $3.430^{\mathrm{a}}$ & 0.025 & 0.96 \\
\hline Casein $(\%)$ & $2.658^{\mathrm{c}}$ & $2.775^{\mathrm{b}}$ & $2.837^{\mathrm{a}}$ & 0.017 & 0.98 \\
\hline Serum protein $(\%)$ & 0.572 & 0.578 & 0.593 & 0.016 & 0.55 \\
\hline $\mathrm{SP}_{\text {permeate portion }} 1$ & 0.588 & 0.594 & 0.610 & 0.016 & 0.56 \\
\hline $\mathrm{CN}^{2} \mathrm{TP}^{2}(\%)$ & 82.3 & 82.8 & 82.7 & 0.004 & 0.49 \\
\hline Fat $(\%)$ & $0.053^{\mathrm{b}}$ & $0.055^{\mathrm{ab}}$ & $0.058^{\mathrm{a}}$ & 0.002 & $>0.99$ \\
\hline Lactose $(\%)$ & $4.830^{\mathrm{b}}$ & $0.177^{\mathrm{c}}$ & $5.051^{\mathrm{a}}$ & 0.030 & $>0.99$ \\
\hline Total calcium $(\mathrm{m} M)$ & $24.01^{\mathrm{a}}$ & $16.94^{\mathrm{b}}$ & $18.16^{\mathrm{b}}$ & 1.723 & 0.88 \\
\hline Soluble calcium $(\mathrm{m} M)$ & $7.64^{\mathrm{a}}$ & $2.35^{\mathrm{b}}$ & $2.32^{\mathrm{b}}$ & 0.360 & $>0.99$ \\
\hline $\mathrm{pH}$ & $6.49^{\mathrm{b}}$ & $6.83^{\mathrm{a}}$ & $6.83^{\mathrm{a}}$ & 0.014 & $>0.99$ \\
\hline
\end{tabular}

${ }^{a-c}$ Means within the same row not followed by the same letter are different $(P<0.05)$.

${ }^{1} \mathrm{SP}_{\text {permeate portion }}=[$ serum protein $/(100-$ casein $)]$.

${ }^{2} \mathrm{CN} \% \mathrm{TP}=($ casein $/$ true protein $) \times 100$.

of the feeds. No differences $(P>0.05)$ in retentate TS, $\mathrm{CP}$, or TP were detected between the initial flux $(55$ $\mathrm{kg} \cdot \mathrm{m}^{-2} \cdot \mathrm{h}^{-1}$ ) and $\mathrm{LF}$ within any of the feeds. This indicated that the retentate protein concentration was not changing with time from the beginning to the end of the processing run. On the other hand, retentate NPN and NCN increased $(P<0.05)$ and $\mathrm{CN}$ decreased $(P$ $<0.05)$ for all feeds from the initial flux to the LF. Differences $(P<0.05)$ in $\mathrm{pH}$ among the retentates were consistent with those of the feeds.

Permeate Composition. Skim milk permeate TS were higher $(P<0.05)$ than MPC $+\mathrm{L}$ permeate TS and $\mathrm{MPC}+\mathrm{L}$ permeate TS were higher $(P<0.05)$ than MPC permeate TS (Table 4). These differences were due to variations in lactose, NPN, and soluble minerals and were consistent with the differences described for the retentates. Fouling reduced $(P<0.05) \mathrm{TP}$ in the MPC+L permeate between the initial flux and LF. Although this trend existed in the skim milk permeates between the initial flux and LF, the reduction was not significant $(P=0.10)$. Differences in permeate NPN among the feeds were consistent with the retentates. However, only NPN in the MPC $+\mathrm{L}$ permeates increased $(P<0.05)$ between the initial flux and the LF. Differences $(P<0.05)$ in $\mathrm{pH}$ among the permeates of the 3 feeds were consistent with those of the feeds and retentates.

\section{Calcium}

The skim milk total Ca concentration (Table 2) was lower than is typically observed ( 25 to $35 \mathrm{mM}$ ) in skim milk, although concentrations as low as 16.2 $\mathrm{m} M$ have been reported (Fox and McSweeney, 1998). Despite this observation, the Ca distribution between the micelles and serum phase was approximately $2: 1$, as would be expected in skim milk (Fox and McSweeney, 1998). Total and soluble Ca were higher $(P<0.05)$ in the skim milk than they were in the MPC or $\mathrm{MPC}+\mathrm{L}$ due to removal of soluble Ca from the MPC85 during

Table 3. Mean $(\mathrm{n}=3)$ compositions of retentates of skim milk, milk protein concentrate (MPC), and MPC with added lactose (MPC $+\mathrm{L})$ produced with a $0.1-\mu \mathrm{m}$ microfiltration process at $55 \mathrm{~kg} \cdot \mathrm{m}^{-2} \cdot \mathrm{h}^{-1}$ or the limiting flux $(\mathrm{LF})^{1}$

\begin{tabular}{|c|c|c|c|c|c|c|c|c|}
\hline Item & Skim, 55 & Skim, LF & MPC, 55 & MPC, LF & $\mathrm{MPC}+\mathrm{L}, 55$ & $\mathrm{MPC}+\mathrm{L}, \mathrm{LF}$ & $\mathrm{SE}$ & $\mathrm{R}^{2}$ \\
\hline $\mathrm{CP}(\%)$ & $8.708^{\mathrm{b}}$ & $8.738^{\mathrm{b}}$ & $8.859^{\mathrm{a}}$ & $8.914^{\mathrm{a}}$ & $8.956^{\mathrm{a}}$ & $8.839^{\mathrm{a}}$ & 0.089 & 0.88 \\
\hline $\mathrm{NPN}^{2}(\%)$ & $0.181^{\mathrm{b}}$ & $0.195^{\mathrm{a}}$ & $0.036^{\mathrm{d}}$ & $0.051^{\mathrm{c}}$ & $0.035^{\mathrm{d}}$ & $0.054^{\mathrm{c}}$ & 0.003 & $>0.99$ \\
\hline True protein ${ }^{2}(\%)$ & $8.528^{\mathrm{b}}$ & $8.543^{\mathrm{b}}$ & $8.823^{\mathrm{a}}$ & $8.864^{\mathrm{a}}$ & $8.921^{\mathrm{a}}$ & $8.785^{\mathrm{a}}$ & 0.088 & 0.93 \\
\hline $\mathrm{CN}^{2}(\%)$ & $7.822^{\mathrm{c}}$ & $7.704^{\mathrm{d}}$ & $8.104^{\mathrm{a}}$ & $8.036^{\mathrm{b}}$ & $8.177^{\mathrm{a}}$ & $7.879^{\mathrm{c}}$ & 0.084 & 0.94 \\
\hline $\mathrm{pH}$ & $6.46^{\mathrm{b}}$ & $6.48^{\mathrm{b}}$ & $6.78^{\mathrm{a}}$ & $6.77^{\mathrm{a}}$ & $6.75^{\mathrm{a}}$ & $6.77^{\mathrm{a}}$ & 0.027 & 0.99 \\
\hline
\end{tabular}

\footnotetext{
${ }^{\mathrm{a}-\mathrm{d}}$ Means within the same row not followed by the same letter are different $(P<0.05)$.

${ }^{1}$ Skim milk, MPC, and MPC+L LF were 91,137 , and $124 \mathrm{~kg} \cdot \mathrm{m}^{-2} \cdot \mathrm{h}^{-1}$, respectively.

${ }^{2} \mathrm{NPN}=$ nonprotein $\mathrm{N} \times 6.38 ; \mathrm{NCN}=$ noncasein $\mathrm{N} \times 6.38$; true protein $=\mathrm{CP}$ minus $\mathrm{NPN} ; \mathrm{CN}=\mathrm{CP}$ minus $\mathrm{NCN}$.
} 
Table 4. Mean $(\mathrm{n}=3)$ compositions of permeates of skim milk, milk protein concentrate (MPC), and MPC with added lactose (MPC+L) produced with a $0.1-\mu \mathrm{m}$ microfiltration process at $55 \mathrm{~kg} \cdot \mathrm{m}^{-2} \cdot \mathrm{h}^{-1}$ or the limiting flux $(\mathrm{LF})^{1}$

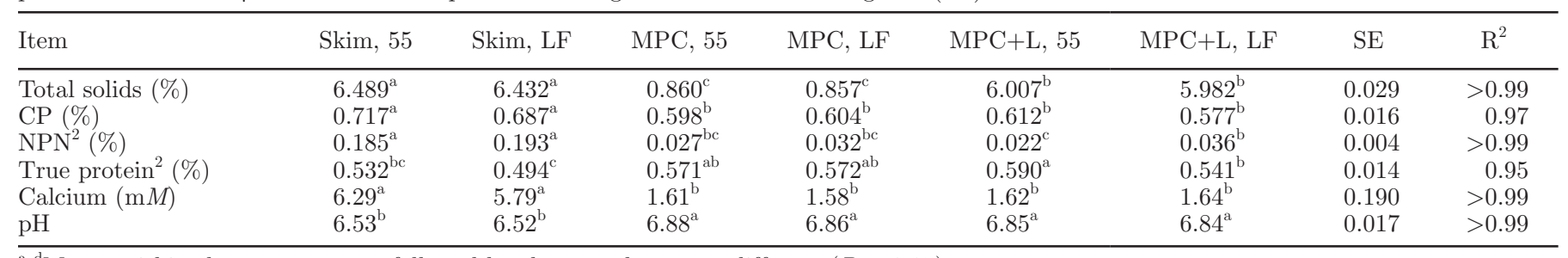

${ }^{\mathrm{a}-\mathrm{d}}$ Means within the same row not followed by the same letter are different $(P<0.05)$.

${ }^{1}$ Skim milk, MPC, and MPC $+\mathrm{L} \mathrm{LF}$ were 91,137 , and $124 \mathrm{~kg} \cdot \mathrm{m}^{-2} \cdot \mathrm{h}^{-1}$, respectively.

${ }^{2} \mathrm{NPN}=$ nonprotein $\mathrm{N} \times 6.38$; true protein $=\mathrm{CP}$ minus $\mathrm{NPN}$.

UF (Table 2). Permeate Ca concentrations (Table 4) depended on the feed. The permeates produced using skim milk contained more $(P<0.05)$ Ca than permeates produced using MPC or MPC $+\mathrm{L}$.

The soluble Ca concentrations determined from each of the feeds' supernatants were higher $(P<0.05)$ than those of their corresponding permeates. Holt et al. (1986) observed a similar discrepancy when quantifying soluble inorganic phosphate in both UF permeate and ultracentrifugation supernatants. This discrepancy could be the result of one or more of the following: the MF membrane rejected a portion of the soluble $\mathrm{Ca}$, small CN micelles that the MF membrane would have rejected remained suspended in the feed supernatants and their colloidal $\mathrm{Ca}$ was calculated as soluble $\mathrm{Ca}$, or the lower separation temperature of the ultracentrifugation procedure $\left(40^{\circ} \mathrm{C}\right.$, the maximum temperature of the centrifuge) increased Ca solubility relative to the $50^{\circ} \mathrm{C} \mathrm{MF}$ procedure, causing the supernatants to have a higher concentration of serum $\mathrm{Ca}$ than the MF permeates. Permeate data from UF trials (Pouliot et al., 1989) suggest that increasing the temperature of skim milk from 40 to $50^{\circ} \mathrm{C}$ can reduce soluble $\mathrm{Ca}$ by about $9 \%$. This would not account for all of the difference between ultracentrifugation and MF observed in the present work because skim milk supernatants contained $22 \%$ more Ca than MF permeates collected at $55 \mathrm{~kg} \cdot \mathrm{m}^{-2} \cdot \mathrm{h}^{-1}$. The work by Pouliot et al. (1989) did not determine whether or not this estimate was due to membrane fouling, temperature-dependent changes in Ca solubility, or a combination of both. Although soluble Ca should pass freely through the membrane, some Ca remains bound to $\alpha$-LA (Brew and Grobler, 1992), which could be partially rejected by the membrane. Ultracentrifugation supernatants were clear, indicating that the $\mathrm{CN}$ micelles had been removed from the suspension. Skim, MPC, and MPC+L supernatants contained 22,46 , and $43 \%$ more Ca than their respective MF permeates collected at $55 \mathrm{~kg} \cdot \mathrm{m}^{-2} \cdot \mathrm{h}^{-1}$, respectively. The variation in these measures suggests that $\mathrm{Ca}$ solubility may best explain this phenomenon.

\section{Soluble Proteins}

The relative amounts of 7 protein fractions were measured in both the ultracentrifugation supernatants (Table 5) and MF permeates (Table 6). A typical electropherogram of skim milk, MPC, and MPC+L supernatants is shown in Figure 1. Within each feed type, electropherograms of the permeates were similar to the supernatants. Skim milk supernatants contained more $(P<0.05)$ of each SP $(\alpha-\mathrm{LA}, \beta-\mathrm{LG}, \mathrm{BSA}$, and lactoferrin) and less $(P<0.05)$ of each $\mathrm{CN}\left(\alpha_{\mathrm{s} 1}-\mathrm{CN}, \beta-\mathrm{CN}\right.$, and $\left.\alpha_{\mathrm{s} 2}-\mathrm{CN}+\kappa-\mathrm{CN}\right)$ than MPC or MPC $+\mathrm{L}$ supernatants. Caseins accounted for $7.9 \%$ of the skim milk supernatant proteins (Table 5), less than the $10 \%$ estimate provided by Morr (1973) after ultracentrifugation at 35 to $40^{\circ} \mathrm{C}$. Skim milk permeate protein was $4.6 \% \mathrm{CN}$ at the initial flux (Table 6), comparable with the $5.4 \%$ determined by Hurt et al. (2015a) when microfiltering skim milk at $50^{\circ} \mathrm{C}$. Skim MF permeates collected at 55 $\mathrm{kg} \cdot \mathrm{m}^{-2} \cdot \mathrm{h}^{-1}$ contained more $(P<0.05) \mathrm{SP}$ and less $(P<$ $0.05) \mathrm{CN}$ than either of the other 2 feeds collected at 55 $\mathrm{kg} \cdot \mathrm{m}^{-2} \cdot \mathrm{h}^{-1}$. The reduced Ca of the MPC and MPC $+\mathrm{L}$ likely weakened the $\mathrm{CN}$ micelle structure in these feeds and caused the differences in soluble CN noted above. Holt et al. (1986) observed that CN rapidly dissociated from the micelles when serum $\mathrm{Ca}^{2+}$ concentrations were below $1 \mathrm{mM}$. The rate of individual $\mathrm{CN}$ migration also differed, with $\kappa$-CN being the most easily removed, then $\beta-\mathrm{CN}$, then $\alpha_{\mathrm{s} 1}-\mathrm{CN}$, then $\alpha_{\mathrm{s} 2}-\mathrm{CN}$ (Holt et al., 1986). Assuming ionic Ca makes up 23\% of the soluble Ca (Walstra et al., 2006), $\mathrm{Ca}^{2+}$ concentrations for the skim milk, MPC, and MPC+L would be approximately 1.76 , 0.54 , and $0.53 \mathrm{~m} M$, respectively, making the MPC and $\mathrm{MPC}+\mathrm{L}$ sera favorable environments for $\mathrm{CN}$ dissociation. In the present study, $\beta-\mathrm{CN}$ and $\alpha_{\mathrm{s} 1}-\mathrm{CN}$ exhibited the most dependence on serum Ca levels, as the relative percentages of these proteins differed the most between the skim milk and MPC in both the supernatants and permeates. Although $\kappa-\mathrm{CN}$ and $\alpha_{\mathrm{s}^{2}-} \mathrm{CN}$ could not be decoupled using the electrophoresis method employed, the sum of these proteins constituted the largest pro- 
Table 5. Mean $(\mathrm{n}=3)$ capillary electrophoresis relative peak areas ( $\%$ of all electropherogram area) of supernatants of skim milk, milk protein concentrate (MPC), and MPC with added lactose (MPC $+\mathrm{L})$ produced by ultracentrifuging feeds at $100,000 \times g$ for $60 \mathrm{~min}$ at $40^{\circ} \mathrm{C}$

\begin{tabular}{|c|c|c|c|c|c|}
\hline Item & Skim & $\mathrm{MPC}$ & $\mathrm{MPC}+\mathrm{L}$ & $\mathrm{SE}$ & $\mathrm{R}^{2}$ \\
\hline$\alpha-L A$ & $21.1^{\mathrm{a}}$ & $14.8^{\mathrm{b}}$ & $14.8^{\mathrm{b}}$ & 0.63 & 0.98 \\
\hline$\beta-L G$ & $49.4^{\mathrm{a}}$ & $37.1^{\mathrm{b}}$ & $39.5^{\mathrm{b}}$ & 1.28 & 0.98 \\
\hline BSA & $5.5^{\mathrm{a}}$ & $4.4^{\mathrm{b}}$ & $4.7^{\mathrm{ab}}$ & 0.37 & 0.84 \\
\hline Lactoferrin & $0.5^{\mathrm{a}}$ & $0.3^{\mathrm{b}}$ & $0.3^{\mathrm{b}}$ & 0.03 & 0.96 \\
\hline Total serum proteins ${ }^{1}$ & $76.6^{\mathrm{a}}$ & $56.5^{\mathrm{b}}$ & $59.3^{\mathrm{b}}$ & 1.27 & $>0.99$ \\
\hline$\alpha_{\mathrm{s} 1}-\mathrm{CN}$ & $1.0^{\mathrm{b}}$ & $6.1^{\mathrm{a}}$ & $5.4^{\mathrm{a}}$ & 0.40 & 0.99 \\
\hline$\beta-\mathrm{CN}$ & $1.8^{\mathrm{c}}$ & $12.7^{\mathrm{a}}$ & $9.7^{\mathrm{b}}$ & 0.98 & 0.98 \\
\hline$\alpha_{\mathrm{s} 2}-\mathrm{CN}+\kappa-\mathrm{CN}$ & $5.2^{\mathrm{b}}$ & $11.2^{\mathrm{a}}$ & $11.1^{\mathrm{a}}$ & 0.24 & $>0.99$ \\
\hline Total $\mathrm{CN}^{1}$ & $7.9^{\mathrm{b}}$ & $30.0^{\mathrm{a}}$ & $26.2^{\mathrm{a}}$ & 1.34 & $>0.99$ \\
\hline
\end{tabular}

${ }^{a-c}$ Means within the same row not followed by the same letter are different $(P<0.05)$.

${ }^{1}$ Total serum proteins $=\alpha-\mathrm{LA}+\beta-\mathrm{LG}+\mathrm{BSA}+$ lactoferrin; total $\mathrm{CN}=\alpha_{\mathrm{s} 1}-\mathrm{CN}+\beta-\mathrm{CN}+\alpha_{\mathrm{s} 2}-\mathrm{CN}+\kappa-\mathrm{CN}$.

portion of $\mathrm{CN}$ in the permeates and supernatants for almost every treatment. If $\kappa$-CN made up the majority of this peak, then the present results would be in line with those of Holt et al. (1986).

Casein micelles are held together primarily through hydrophobic and electrostatic interactions, the former of which is diminished at lower temperatures and the latter of which is diminished upon removal of $\mathrm{Ca}$ or phosphate. By removing soluble minerals through UF, the hydrophobic interactions become more important at maintaining micelle integrity, so temperature should affect $\mathrm{CN}$ dissociation to a greater extent. This was best demonstrated by the relative increase in $\beta-\mathrm{CN}$ between the supernatants and permeates of the skim milk and MPC. The ratios of soluble $\mathrm{CN}$ in the skim supernatants (collected at $40^{\circ} \mathrm{C}$ ) to those in the skim milk MF permeates (collected at $50^{\circ} \mathrm{C}$ ) were $1.49,2.03$, and 1.66 for $\alpha_{\mathrm{s} 1}-\mathrm{CN}, \beta-\mathrm{CN}$, and $\alpha_{\mathrm{s} 2}+\kappa-\mathrm{CN}$, respectively. The same ratios for the MPC supernatants and permeates were $2.33,5.05$, and 1.38 . If smaller micelles preferentially remained in the supernatant, the ratio for $\kappa-\mathrm{CN}$ should be the highest by virtue of its location on the surface of the micelles (Davies and Law, 1983). On the contrary, $\beta-\mathrm{CN}$ (the most hydrophobic and therefore the most temperature dependent) had the highest ratio and increased the most when $\mathrm{Ca}$ was removed from the feed (i.e., between MPC and skim), indicating that the discrepancy is likely a temperature effect rather than one driven by unsedimented micelles. Consequently, if the MF process were conducted at a lower temperature (i.e., $40^{\circ} \mathrm{C}$ ), it could be expected that the permeate would contain more soluble $\mathrm{CN}$.

\section{Apparent Viscosities of Feeds, Retentates, and Permeates}

The viscosity of the MPC was lower $(P<0.05)$ than the viscosities of the skim milk and $\mathrm{MPC}+\mathrm{L}$ (Table 7) due to the lower lactose concentration of the MPC
(Table 2). No differences in the viscosities of the skim milk and $\mathrm{MPC}+\mathrm{L}$ were detected $(P>0.05)$ and both were similar to the viscosity of skim milk reported by Fernandez-Martin (1972). No difference in the viscosities of the skim milk retentate and MPC retentate was detected $(P>0.05)$, but both were lower than the viscosity of $\mathrm{MPC}+\mathrm{L}$ retentate (Table 7 ). These differences were driven by the higher protein concentrations in the MPC and $\mathrm{MPC}+\mathrm{L}$ retentates relative to skim milk retentate and the higher lactose concentrations of the skim milk and MPC $+\mathrm{L}$ retentates relative to MPC retentate. No difference in the viscosities of the skim milk permeate and $\mathrm{MPC}+\mathrm{L}$ permeate were detected $(P>0.05)$, but both were higher than $(P<0.05)$ the MPC permeate viscosity (Table 7 ). These differences were caused by variations in lactose concentrations. Tang et al. (1993) determined that the viscosity temperature dependence of whey protein solutions was well

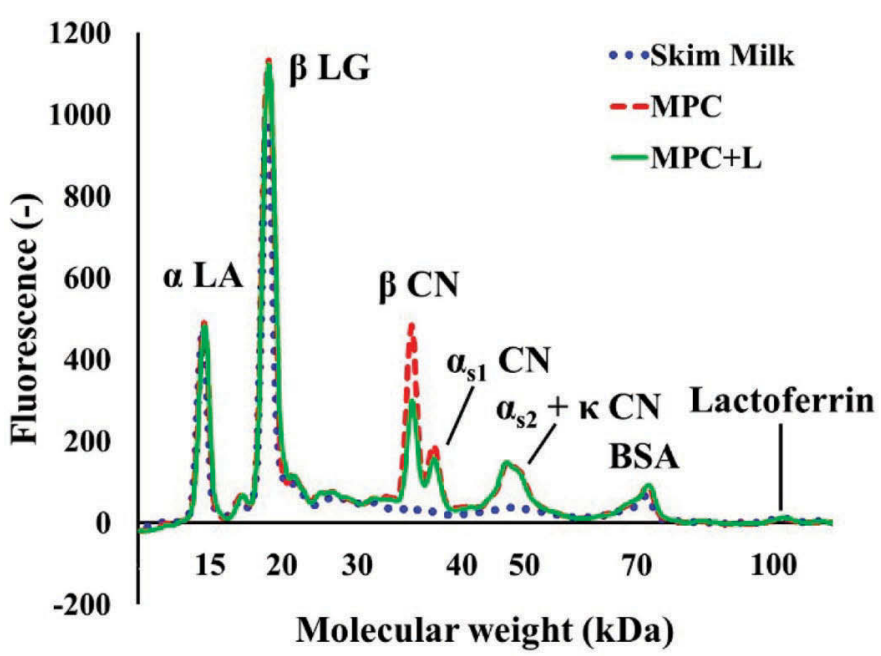

Figure 1. Typical capillary electropherograms of ultracentrifugation $\left(100,000 \times g, 60 \mathrm{~min}, 40^{\circ} \mathrm{C}\right)$ supernatants of skim milk, milk protein concentrate $(\mathrm{MPC})$, or MPC with added lactose $(\mathrm{MPC}+\mathrm{L})$. Color version available online. 
Table 6. Mean $(\mathrm{n}=3)$ capillary electrophoresis relative peak areas (\% of all electropherogram area) of permeates of skim milk, milk protein concentrate $(\mathrm{MPC})$, and MPC with added lactose $(\mathrm{MPC}+\mathrm{L})$ produced with a $0.1-\mu \mathrm{m}$ microfiltration process at $55 \mathrm{~kg} \cdot \mathrm{m}^{-2} \cdot \mathrm{h}^{-1}$ or the limiting flux $(\mathrm{LF})^{1}$

\begin{tabular}{|c|c|c|c|c|c|c|c|c|}
\hline Item & Skim, 55 & Skim, LF & MPC, 55 & $\mathrm{MPC}, \mathrm{LF}$ & $\mathrm{MPC}+\mathrm{L}, 55$ & $\mathrm{MPC}+\mathrm{L}, \mathrm{LF}$ & $\mathrm{SE}$ & $\mathrm{R}^{2}$ \\
\hline$\alpha-\mathrm{LA}$ & $22.5^{\mathrm{ab}}$ & $24.6^{\mathrm{a}}$ & $18.1^{\mathrm{b}}$ & $22.0^{\mathrm{ab}}$ & $17.5^{\mathrm{b}}$ & $21.9^{\mathrm{ab}}$ & 1.73 & 0.88 \\
\hline$\beta-\mathrm{LG}$ & $58.5^{\mathrm{a}}$ & $57.2^{\mathrm{ab}}$ & $48.8^{b}$ & $52.3^{\mathrm{ab}}$ & $54.0^{\mathrm{ab}}$ & $59.0^{\mathrm{a}}$ & 2.63 & 0.88 \\
\hline $\mathrm{BSA}$ & 5.0 & 4.7 & 5.2 & 4.9 & 5.6 & 4.4 & 0.66 & 0.83 \\
\hline Lactoferrin & 0.6 & 0.5 & 0.4 & 0.5 & 0.5 & 0.4 & 0.15 & 0.86 \\
\hline Total serum proteins ${ }^{2}$ & $86.6^{\mathrm{a}}$ & $87.0^{\mathrm{a}}$ & $72.6^{\mathrm{b}}$ & $79.7^{\mathrm{ab}}$ & $77.5^{\mathrm{ab}}$ & $85.7^{\mathrm{a}}$ & 3.91 & 0.89 \\
\hline$\alpha_{\mathrm{s} 1}-\mathrm{CN}$ & $0.7^{\mathrm{b}}$ & $0.1^{\mathrm{b}}$ & $2.6^{\mathrm{a}}$ & $2.0^{\mathrm{a}}$ & $2.3^{\mathrm{a}}$ & $0.6^{\mathrm{b}}$ & 0.30 & 0.97 \\
\hline$\beta-\mathrm{CN}$ & $0.9^{\mathrm{bc}}$ & $0.3^{\mathrm{c}}$ & $2.5^{\mathrm{a}}$ & $1.5^{\mathrm{abc}}$ & $2.0^{\mathrm{ab}}$ & $0.7^{\mathrm{bc}}$ & 0.42 & 0.92 \\
\hline$\alpha_{\mathrm{s} 2}-\mathrm{CN}+\kappa-\mathrm{CN}$ & $3.1^{\mathrm{bc}}$ & $0.7^{\mathrm{c}}$ & $8.1^{\mathrm{a}}$ & $6.2^{\mathrm{ab}}$ & $7.5^{\mathrm{a}}$ & $3.0^{\mathrm{bc}}$ & 1.10 & 0.95 \\
\hline Total $\mathrm{CN}^{2}$ & $4.6^{\mathrm{bc}}$ & $1.1^{\mathrm{c}}$ & $13.3^{\mathrm{a}}$ & $9.7^{\mathrm{ab}}$ & $11.7^{\mathrm{a}}$ & $4.3^{\mathrm{c}}$ & 1.64 & 0.96 \\
\hline
\end{tabular}

${ }^{\mathrm{a}-\mathrm{c}}$ Means within the same row not followed by the same letter are different $(P<0.05)$.

${ }^{1}$ Skim milk, MPC, and MPC+L LF were 91,137 , and $124 \mathrm{~kg} \cdot \mathrm{m}^{-2} \cdot \mathrm{h}^{-1}$, respectively.

${ }^{2}$ Total serum proteins $=\alpha-\mathrm{LA}+\beta-\mathrm{LG}+\mathrm{BSA}+$ lactoferrin; total $\mathrm{CN}=\alpha_{\mathrm{s} 1}-\mathrm{CN}+\beta-\mathrm{CN}+\alpha_{\mathrm{s} 2}-\mathrm{CN}+\kappa-\mathrm{CN}$.

described by the Arrhenius equation at temperatures between 5 and $60^{\circ} \mathrm{C}$ when TS were $<30 \%$. Morison and Mackay (2001) determined that the Arrhenius equation adequately described lactose solution viscosity temperature sensitivity in the range of 10 to $50^{\circ} \mathrm{C}$. Arrhenius estimates of MF permeate viscosities in the present study were compared with results from the predictive equations for viscosity described by Morison and Mackay (2001), which took into account anhydrous lactose concentration and temperature. All estimates in the present study were approximately $5 \%$ higher than those predicted by Morison and Mackay (2001). These differences could be the result of the additional SP in MF permeate that were not present in the lactose solutions used to construct the predictive equations. The viscosity of skim MF permeate measured by Piry et al. (2012) at $55^{\circ} \mathrm{C}$ was $0.570 \mathrm{mPa} \cdot \mathrm{s}$ and equivalent to that predicted by the equations of Morison and Mackay (2001). The viscosity of deionized water at $50^{\circ} \mathrm{C}$ was also estimated using the method described in the present work. The estimated value for water at $50^{\circ} \mathrm{C}$ was $0.560 \mathrm{mPa} \cdot \mathrm{s}, 2.4 \%$ higher than the published value of $0.547 \mathrm{mPa} \cdot \mathrm{s}$ (Weast et al., 1988).

\section{MF Processing Data}

Mean temperature and $\mathrm{CF}$ among all treatments were $50^{\circ} \mathrm{C}$ and $2.94 \times$, respectively, and no differences were detected among feed treatments or fluxes $(P>0.05)$.
Pressures. The GP membranes used in this study are equipped with a permeability gradient along the outside length of the membrane which decreases in resistance from inlet to outlet (Zulewska et al., 2009). This design promotes even permeation along the membrane length and reduces fouling (Garcera and Toujas, 2002). To optimize these benefits, the manufacturer of the GP membranes recommends that they be operated at a $\Delta \mathrm{P}$ that is between 200 and $220 \mathrm{kPa}$ (Jacques Guibaud, Pall Corp. Food \& Beverage, Bazet, France, personal communication). In this study, $\Delta \mathrm{P}$ was held constant at $220 \mathrm{kPa}$ and no changes were noted among feeds or fluxes $(P>0.05$; Table 8$)$. Because the feed pump used in the MF system was not equipped with a variable frequency drive, $\mathrm{P}_{\mathrm{Ro}}$ was fixed and dependent on the feed viscosity. Therefore, $\Delta \mathrm{P}$ had to be controlled by changing $\mathrm{P}_{\mathrm{Ri}}$ with the retentate recirculation pump. The $\mathrm{P}_{\mathrm{Ri}}$ and $\mathrm{P}_{\mathrm{Ro}}$ of the MPC treatment were lower $(P<0.05)$ than those of the skim and MPC $+\mathrm{L}$ treatments (Table 8$)$ as a result of the lower $(P<0.05)$ viscosity of the MPC feed (Table 7). No change in $\mathrm{P}_{\mathrm{Ri}}$ or $\mathrm{P}_{\mathrm{Ro}}$ with flux was detected $(P>0.05)$ within any of the feed treatments (Table 8 ). Regardless of feed treatment, $\mathrm{P}_{\mathrm{Pi}}$ decreased $(P<0.05)$ and $\mathrm{TMP}_{\mathrm{i}}$ increased $(P<0.05)$ as backpressure on the permeate side was reduced to increase flux and fouling progressed (Table 8). At the LF, the skim and MPC $+\mathrm{L}$ treatments had similar TMP $(P>0.05)$, but TMP at the MPC LF was lower $(P<0.05$; Table 8$)$. These differences were likely

Table 7. Mean ( $\mathrm{n}=3$ for feed and permeates; $\mathrm{n}=15$ for retentates) apparent viscosities $\left(\mathrm{mPa} \cdot \mathrm{s}, 50^{\circ} \mathrm{C}, 73 \mathrm{~s}^{-1}\right)$ of feeds, retentates, and permeates produced by microfiltering skim milk, milk protein concentrate (MPC), and MPC with added lactose $(\mathrm{MPC}+\mathrm{L})$ using $0.1-\mu \mathrm{m}$ graded permeability membranes

\begin{tabular}{lccccc}
\hline Item & Skim & MPC & MPC $+\mathrm{L}$ & $\mathrm{SE}$ & $\mathrm{R}^{2}$ \\
\hline Feed & $0.92^{\mathrm{a}}$ & $0.82^{\mathrm{b}}$ & $0.93^{\mathrm{a}}$ & 0.009 & 0.99 \\
Retentate & $1.68^{\mathrm{b}}$ & $1.59^{\mathrm{b}}$ & $1.83^{\mathrm{a}}$ & 0.048 & 0.87 \\
Permeate & $0.65^{\mathrm{a}}$ & $0.58^{\mathrm{b}}$ & $0.66^{\mathrm{a}}$ & 0.011 & 0.96 \\
\hline
\end{tabular}

$\overline{a, b}$ Means within the same row not followed by the same letter are different $(P<0.05)$. 
not important, as attempting to increase the flux of the MPC treatment from 137 to $140 \mathrm{~kg} \cdot \mathrm{m}^{-2} \cdot \mathrm{h}^{-1}$ resulted in a simultaneous decrease in flux and a dramatic increase in TMP (Figure 2). Because $\mathrm{P}_{\mathrm{P}_{0}}$ was calculated based on $\mathrm{P}_{\mathrm{Pi}}, \mathrm{P}_{\mathrm{Po}_{\mathrm{o}}}$ and $\mathrm{TMP}_{\mathrm{o}}$ changed to the same extent as $\mathrm{P}_{\mathrm{Pi}}$ and $\mathrm{TMP}_{\mathrm{i}}$, respectively (Table 8). In all treatments, the response of flux to TMP became heavily nonlinear as $\mathrm{TMP}_{\text {avg }}$ approached $150 \mathrm{kPa}$ (Figure 2). This estimate of $\mathrm{TMP}_{\text {avg }}$ was consistent with the work done by Hurt et al. (2015b) when determining the LF of MPC retentates at different protein concentrations. Consequently, $150 \mathrm{kPa}$ could serve as a maximum $\mathrm{TMP}_{\text {avg }}$ guideline for manufacturers with GP membranes to use to control membrane fouling.

If pressure on the permeate side of the membrane exceeds pressure on the retentate side of the membrane, reverse or Starling flow will occur (Zulewska et al., 2009). This condition is detrimental to the membrane process because it results in permeate flowing back into the retentate, thereby reducing the effective membrane surface area available to separate the feed. Starling flow was observed at the membrane outlets for all feed materials at $55 \mathrm{~kg} \cdot \mathrm{m}^{-2} \cdot \mathrm{h}^{-1}$, as evidenced by negative $\mathrm{TMP}_{\mathrm{o}}$ (Table 8). Starling flow was reduced by increasing flux (reducing backpressure on the permeate side of the membrane) and $\mathrm{TMP}_{\mathrm{o}}$ became positive for the skim, MPC, and MPC $+\mathrm{L}$ treatments at 75, 115, and $100 \mathrm{~kg} \cdot \mathrm{m}^{-2} \cdot \mathrm{h}^{-1}$, respectively (Figure 3 ). These values could serve as useful minimum fluxes that would ensure the entire length of the membrane is being used.

Resistance Calculations. The clean membrane resistance $\left(2.83 \times 10^{12} \pm 0.008 \times 10^{12} \mathrm{~m}^{-1}\right)$ determined at the start of each run with only the feed pump running and the permeate valve fully opened remained constant $(P>0.05)$ throughout the study. This indicated that the membrane was cleaned sufficiently between processing trials and that the clean membrane resistance was the same among treatments. Despite its usefulness as a tool to confirm that the membrane had been cleaned, it was discovered that this value did not give an accurate representation of the resistance due to the clean membrane during processing. For example, if the retentate recirculation pump was turned on in addition to the feed pump when processing $50^{\circ} \mathrm{C} \mathrm{RO}$ water, the calculated resistance of the clean membrane was $6.88 \times 10^{12} \mathrm{~m}^{-1}$ at $55 \mathrm{~kg} \cdot \mathrm{m}^{-2} \cdot \mathrm{h}^{-1}$ and decreased logarithmically $\left(\mathrm{R}^{2}>0.99\right)$ as the flux was increased to $380 \mathrm{~kg} \cdot \mathrm{m}^{-2} \cdot \mathrm{h}^{-1}$. Although this value was affected by the flux and not the status of the retentate recirculation pump (on or off), the resistances due to the clean membrane were calculated based on values determined at each flux while the retentate recirculation pump and feed pump were on while processing $50^{\circ} \mathrm{C}$ RO water.

The fouling ratios determined for all 3 feeds (Figure 4) were not different $(P>0.05)$ from one another at $55 \mathrm{~kg} \cdot \mathrm{m}^{-2} \cdot \mathrm{h}^{-1}$. At the LF, however, the skim milk fouling ratio was higher $(P<0.05)$ than both the MPC and $\mathrm{MPC}+\mathrm{L}$ fouling ratios, which were not different $(P>0.05)$ themselves. Only the MPC fouling ratio did not change $(P>0.05)$ from the initial flux to the LF. While microfiltering $55^{\circ} \mathrm{C}$ skim milk using $0.1-\mu \mathrm{m}$ zirconia membranes of 4 different resistances, Piry et al. (2012) determined that pressure-independent fouling proceeded rapidly at fouling ratios above 1.33, regardless of which of the 4 membranes were used. The present study's findings were in agreement with this value, as the fouling ratios determined at the LF were 2.30 for skim milk, 0.58 for MPC, and 1.36 for MPC+L. It should also be noted that skim milk TMP began to increase rapidly as flux was increased to $85 \mathrm{~kg} \cdot \mathrm{m}^{-2} \cdot \mathrm{h}^{-1}$. At this point, the skim milk fouling ratio was 1.08 , slightly below that of the 1.33 observed by Piry et al.

Table 8. Mean $(\mathrm{n}=3)$ gauge pressures ${ }^{1}(\mathrm{kPa})$ at $55 \mathrm{~kg} \cdot \mathrm{m}^{-2} \cdot \mathrm{h}^{-1}$ and limiting fluxes $(\mathrm{LF})^{2}$ when microfiltering skim milk, milk protein concentrate (MPC), or MPC with added lactose (MPC+L) using 0.1- $\mu$ m graded permeability membranes

\begin{tabular}{lcccrrrrr}
\hline Item & $\mathrm{P}_{\mathrm{Ri}}$ & $\mathrm{P}_{\mathrm{Ro}}$ & $\Delta \mathrm{P}$ & $\mathrm{P}_{\mathrm{Pi}}$ & $\mathrm{P}_{\mathrm{Po}}$ & $\mathrm{TMP}_{\mathrm{i}}$ & $\mathrm{TMP}_{\mathrm{o}}$ & TMP $_{\text {avg }}$ \\
\hline Skim, 55 & $450^{\mathrm{a}}$ & $230^{\mathrm{a}}$ & 220 & $257^{\mathrm{a}}$ & $271^{\mathrm{a}}$ & $208^{\mathrm{c}}$ & $-39^{\mathrm{c}}$ & $85^{\mathrm{c}}$ \\
Skim, LF & $450^{\mathrm{a}}$ & $230^{\mathrm{a}}$ & 220 & $52^{\mathrm{c}}$ & $66^{\mathrm{c}}$ & $413^{\mathrm{a}}$ & $166^{\mathrm{a}}$ & $290^{\mathrm{a}}$ \\
MPC, 55 & $446^{\mathrm{b}}$ & $226^{\mathrm{b}}$ & 220 & $270^{\mathrm{a}}$ & $284^{\mathrm{a}}$ & $192^{\mathrm{c}}$ & $-56^{\mathrm{c}}$ & $68^{\mathrm{c}}$ \\
MPC, LF & $446^{\mathrm{b}}$ & $226^{\mathrm{b}}$ & 220 & $180^{\mathrm{b}}$ & $193^{\mathrm{b}}$ & $283^{\mathrm{b}}$ & $35^{\mathrm{b}}$ & $159^{\mathrm{b}}$ \\
MPC+L, 55 & $450^{\mathrm{a}}$ & $230^{\mathrm{a}}$ & 220 & $270^{\mathrm{a}}$ & $284^{\mathrm{a}}$ & $195^{\mathrm{c}}$ & $-52^{\mathrm{c}}$ & $71^{\mathrm{c}}$ \\
MPC+L, LF & $450^{\mathrm{a}}$ & $230^{\mathrm{a}}$ & 220 & $104^{\mathrm{c}}$ & $118^{\mathrm{c}}$ & $366^{\mathrm{a}}$ & $119^{\mathrm{a}}$ & $242^{\mathrm{a}}$ \\
SE & 0.12 & $<0.01$ & 0.12 & 17.42 & 17.42 & 20.53 & 20.64 & 20.58 \\
$\mathrm{R}^{2}$ & $>0.99$ & $>0.99$ & 0.65 & 0.99 & 0.99 & 0.98 & 0.98 & 0.98 \\
\hline
\end{tabular}

${ }^{\mathrm{a}-\mathrm{c}}$ Means within the same column not followed by the same letter are different $(P<0.05)$.

${ }^{1} \mathrm{P}_{\mathrm{Ri}}=$ inlet retentate pressure; $\mathrm{P}_{\mathrm{Ro}}=$ outlet retentate pressure; $\Delta \mathrm{P}=\mathrm{P}_{\mathrm{Ri}}-\mathrm{P}_{\mathrm{Ro}} ; \mathrm{P}_{\mathrm{Pi}}=$ inlet permeate pressure; $\mathrm{P}_{\mathrm{po}}=$ outlet permeate pressure; $\mathrm{TMP}_{\mathrm{i}}=$ transmembrane pressure at the inlet; $\mathrm{TMP}_{\mathrm{o}}=$ transmembrane pressure at the outlet; $\mathrm{TMP}_{\mathrm{avg}}=\left(\mathrm{TMP}_{\mathrm{i}}+\mathrm{TMP}_{\mathrm{o}}\right) / 2$.

${ }^{2}$ Skim milk, MPC, and MPC $+\mathrm{L} \mathrm{LF}$ were 91,137 , and $124 \mathrm{~kg} \cdot \mathrm{m}^{-2} \cdot \mathrm{h}^{-1}$, respectively. 


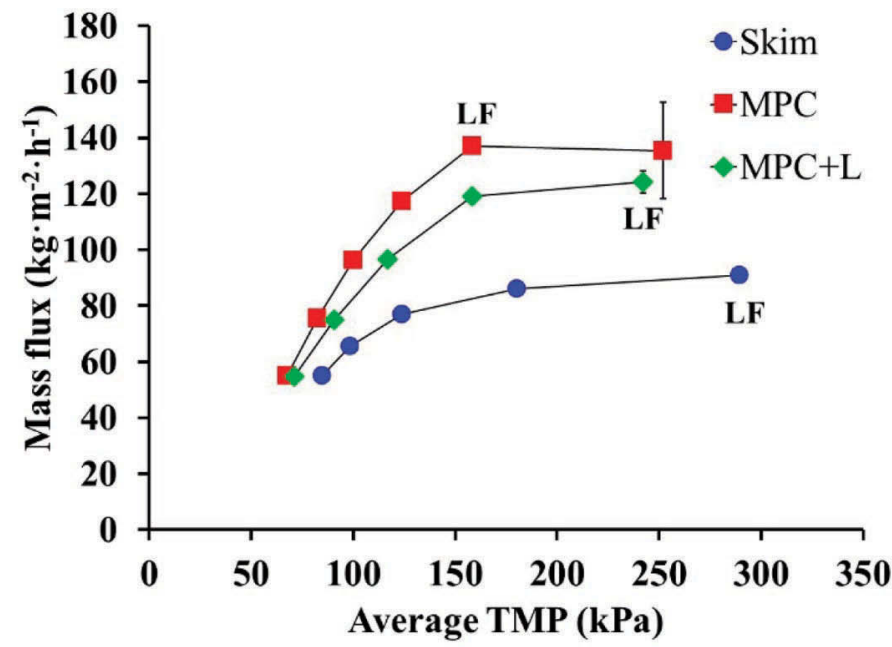

Figure 2. Mean $(\mathrm{n}=3)$ mass flux as a function of average transmembrane pressure (TMP) when microfiltering skim milk, milk protein concentrate (MPC), or MPC with added lactose $(\mathrm{MPC}+\mathrm{L})$. Temperature $=50^{\circ} \mathrm{C}$; pressure drop across membrane length $=220$ $\mathrm{kPa}$. Error bars represent \pm 1 standard deviation. Points of limiting fluxes are noted as LF. Color version available online.

(2012). Also, the further increase in MPC TMP above its LF produced a fouling ratio of 1.67 , above the value reported by Piry et al. (2012).

An electrical outage occurred during one of the MPC experimental runs (data from that run were not used in this study's analysis and the run was repeated). This caused the MF system's pumps to shut down for approximately $30 \mathrm{~s}$. When the system was restarted,

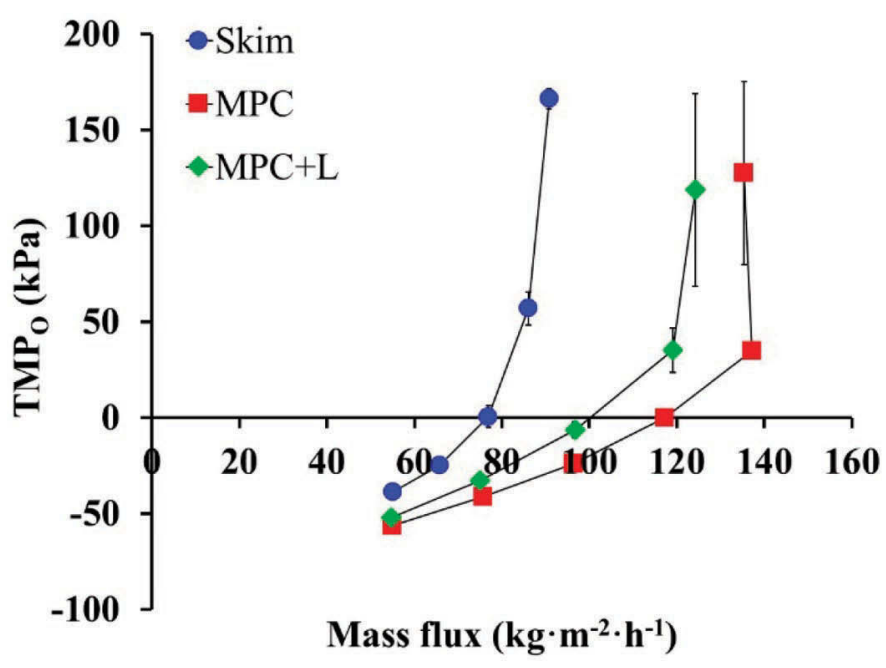

Figure 3. Mean $(\mathrm{n}=3)$ transmembrane pressure at the outlet end of the membrane $\left(\mathrm{TMP}_{\mathrm{o}}\right)$ as a function of mass flux when microfiltering skim milk, milk protein concentrate (MPC), or MPC with added lactose $(\mathrm{MPC}+\mathrm{L})$. Error bars represent \pm 1 standard deviation. Color version available online.

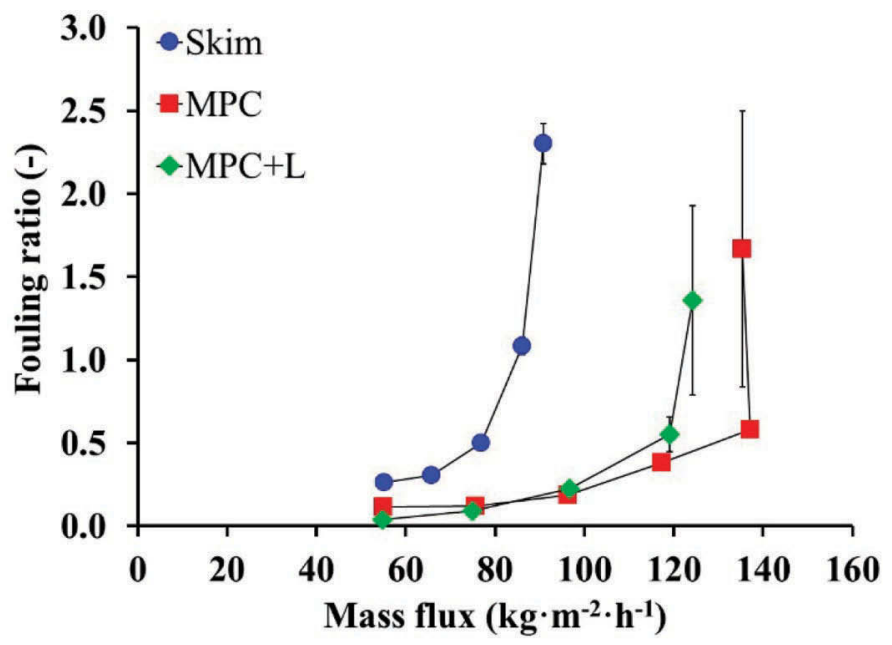

Figure 4. Mean $(\mathrm{n}=3)$ fouling ratios (resistance due to the concentration polarization gel layer and fouling divided by resistance of the clean membrane) as a function of mass flux when microfiltering either skim milk, milk protein concentrate (MPC), or MPC with added lactose $(\mathrm{MPC}+\mathrm{L})$. Error bars represent \pm 1 standard deviation. Color version available online.

TMP and flux were restored to preoutage values within 15 min, but permeate TP was permanently reduced by $33 \%$. Taken with equation 1 , this implies that although SP passage may decline as membrane resistance increases, the converse is not necessarily true. Only a moderate correlation $\left(\mathrm{R}^{2}=0.59\right)$ between the SP removal factors and the fouling ratios was observed, indicating that resistance calculations may not be the most useful measures for comparing mass transfer data. This experience demonstrated the importance of maintaining a high cross-flow velocity in the retentate recirculation loop throughout the processing run.

Hydrodynamic Conditions. Because retentate viscosities and densities of the skim milk and $\mathrm{MPC}+\mathrm{L}$ treatments were higher than those of the MPC treatment $\left(\mathrm{MPC}\right.$ retentate $=1,019 \mathrm{~kg} \cdot \mathrm{m}^{-3}$, skim and $\mathrm{MPC}+\mathrm{L}$ retentates $=1,040 \mathrm{~kg} \cdot \mathrm{m}^{-3}$ at $50^{\circ} \mathrm{C}$ ) and $\Delta \mathrm{P}$ was maintained at $220 \mathrm{kPa}$, cross-flow velocities of the skim milk and MPC $+\mathrm{L}$ treatments were lower $(P$ $<0.05)$ than those of the MPC treatment (Table 9). All Reynolds numbers indicated turbulent flow (Re > $4,000)$, but differences in retentate viscosities resulted in MPC flow being more turbulent $(P<0.05)$ than skim milk flow and skim milk flow being more turbulent $(P<0.05)$ than MPC $+\mathrm{L}$ flow (Table 9$)$.

Limiting Fluxes. The maximum fluxes obtainable by increasing TMP were identified for each feed treatment as the LF. The LF for skim milk $\left(91 \mathrm{~kg} \cdot \mathrm{m}^{-2} \cdot \mathrm{h}^{-1}\right)$ was lower $(P<0.05)$ than that of $\mathrm{MPC}+\mathrm{L}(124$ $\left.\mathrm{kg} \cdot \mathrm{m}^{-2} \cdot \mathrm{h}^{-1}\right)$, which was lower $(P<0.05)$ than that of 
Table 9. Mean $(\mathrm{n}=3)$ retentate cross-flow parameters at $55 \mathrm{~kg} \cdot \mathrm{m}^{-2} \cdot \mathrm{h}^{-1}$ and limiting fluxes $(\mathrm{LF})^{1}$ when microfiltering skim milk, milk protein concentrate (MPC), or MPC with added lactose (MPC+L) using $0.1-\mu \mathrm{m}$ graded permeability membranes

\begin{tabular}{lccc}
\hline & $\begin{array}{c}\text { Retentate } \\
\text { recirculation rate } \\
\left(\mathrm{L} \cdot \mathrm{min}^{-1}\right)\end{array}$ & $\begin{array}{c}\text { Retentate } \\
\text { cross-flow velocity } \\
\left(\mathrm{m} \cdot \mathrm{s}^{-1}\right)\end{array}$ & $\begin{array}{c}\text { Retentate } \\
\text { Reynolds } \\
\text { number }\end{array}$ \\
\hline Skim, 55 & $742^{\mathrm{b}}$ & $7.40^{\mathrm{b}}$ & $18,800^{\mathrm{b}}$ \\
Skim, LF & $740^{\mathrm{c}}$ & $7.38^{\mathrm{c}}$ & $18,400^{\mathrm{b}}$ \\
MPC, 55 & $758^{\mathrm{a}}$ & $7.55^{\mathrm{a}}$ & $19,700^{\mathrm{a}}$ \\
MPC, LF & $759^{\mathrm{a}}$ & $7.56^{\mathrm{a}}$ & $19,600^{\mathrm{a}}$ \\
MPC+L, 55 & $742^{\mathrm{bc}}$ & $7.40^{\mathrm{bc}}$ & $16,600^{\mathrm{c}}$ \\
MPC+L, LF & $742^{\mathrm{b}}$ & $7.40^{\mathrm{b}}$ & $17,300^{\mathrm{c}}$ \\
SE & 0.58 & 0.01 & 390 \\
$\mathrm{R}^{2}$ & $>0.99$ & $>0.99$ & 0.96 \\
\hline
\end{tabular}

${ }^{\mathrm{a}-\mathrm{c}}$ Means within the same column not followed by the same letter are different $(P<0.05)$.

${ }^{1}$ Skim milk, MPC, and MPC+L LF were 91,137 , and $124 \mathrm{~kg} \cdot \mathrm{m}^{-2} \cdot \mathrm{h}^{-1}$, respectively.

MPC $\left(137 \mathrm{~kg} \cdot \mathrm{m}^{-2} \cdot \mathrm{h}^{-1}\right)$ (Figure 2). The difference in LF between the skim milk and $\mathrm{MPC}+\mathrm{L}$ treatments was due to differences in all nonlactose soluble components and was associated with differences in soluble Ca. The difference in $\mathrm{LF}$ between the MPC and MPC+L treatments was solely due to the difference in lactose concentrations. Because the MPC and MPC+L retentates contained more protein than the skim retentate, the absolute differences in LF between MPC and skim milk or $\mathrm{MPC}+\mathrm{L}$ and skim milk cannot be attributed solely to the differences in lactose and soluble mineral contents. However, in our experience (Hurt et al., 2015b) the small differences in protein observed among retentates in this study $(<0.4 \%)$, although statistically significant, likely made little practical difference in the LF results. Despite the MPC $+\mathrm{L}$ retentate having a higher viscosity and higher protein concentration than skim milk retentate, MPC+L LF was $36 \%$ higher than the skim LF. As a consequence of its reduced soluble mineral content, the ionic strength of MPC+L is lower than that of skim milk. At lower ionic strength, steric repulsions between CN micelles are enhanced due to a reduction in charge shielding of micelle surfaces. This increase in repulsive forces would make it more difficult for $\mathrm{CN}$ micelles to accumulate with one another near the surface of the membrane and cause fouling (Jimenez-Lopez et al., 2008). Further, the reduction in soluble Ca observed in the $\mathrm{MPC}+\mathrm{L}$ relative to skim milk would be expected to reduce electrostatic salt bridging between divalent $\mathrm{Ca}$ and the negatively charged carboxyl groups of the caseins.

Beliciu and Moraru (2009) observed a 40\% increase in average $\mathrm{CN}$ micelle diameter when $50^{\circ} \mathrm{C}$ water was used to disperse the micelles instead of $50^{\circ} \mathrm{C}$ UF permeate of skim milk. In addition, they observed a time-dependent decrease in their particle size analyzer's signal intensity when skim milk was measured in water. This decrease in signal intensity was not observed when the skim milk was measured in UF permeate, and the authors concluded that dilution with water must have caused some micellar dissociation. No particle size analyses were performed in the present work. However, it is reasonable to deduce that larger $\mathrm{CN}$ micelles would produce a more open foulant layer than smaller CN micelles. Particles smaller than the membrane pore size are known to contribute to depth fouling, those of about the same size can block pores, and those that are much larger than the membrane pores contribute to cake layer formation (Tan et al., 2014). If the micelle diameter were indeed increased, the mechanism for fouling may have shifted away from pore constriction and toward cake layer formation, the latter of which may also be less dense in a reduced-Ca environment. Each of these factors could contribute to the higher LF observed when microfiltering MPC and MPC+L.

Using tubular polyethersulfone membranes, Rao et al. (1994) observed a $24 \%$ decrease in UF flux at $25^{\circ} \mathrm{C}$ when a $4.5 \%$ lactose solution was processed instead of pure water. This decrease was attributed both to the added $\mathrm{Ca}$ contributed by the lactose powder and the $21 \%$ increase in viscosity caused by the addition of lactose. In the present study, the addition of lactose to MPC did not change the Ca concentration (Table 2), but it increased the retentate viscosity by $15 \%$ (Table 7) and decreased the limiting flux by $9 \%$ (Table 1 ). Reynolds numbers have been shown to linearly affect LF in ceramic MF of skim milk (Samuelsson et al., 1997a,b). The difference between the MPC and MPC+L Reynolds numbers at the LF (MPC was $13 \%$ higher, Table 9) was comparable with the increase in the LF (MPC was $10.5 \%$ higher, Table 1). Because the relative difference in $\mathrm{LF}$ between $\mathrm{MPC}$ and $\mathrm{MPC}+\mathrm{L}$ caused by lactose addition was less than relative differences in viscosity and Reynolds number caused by 


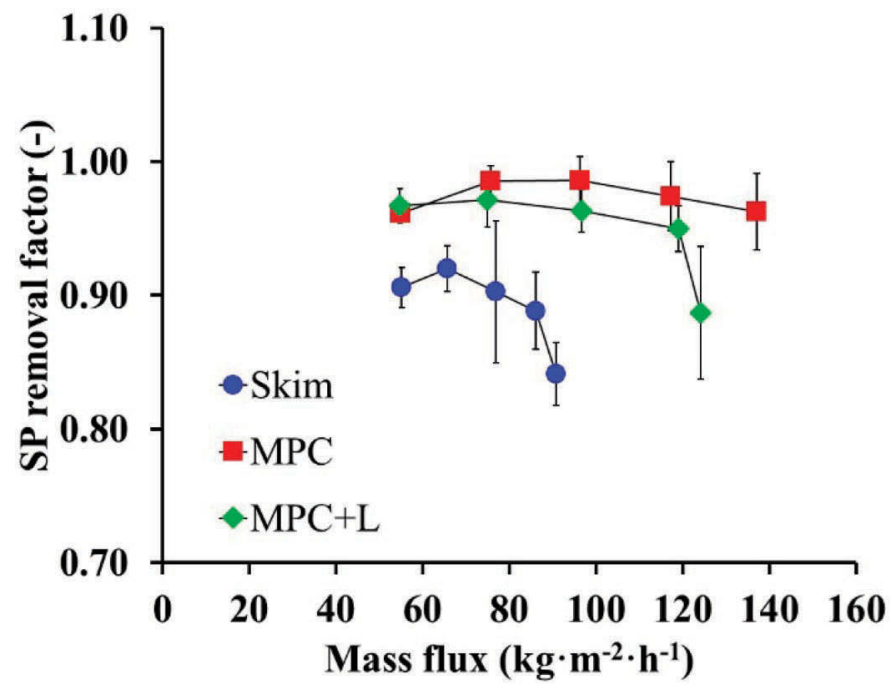

Figure 5. Mean $(\mathrm{n}=3)$ serum protein $(\mathrm{SP})$ removal factors (true protein in permeate divided by SP in the permeate portion of the feed) as a function of mass flux when microfiltering skim milk, milk protein concentrate (MPC), or MPC with added lactose (MPC+L). Error bars represent \pm 1 standard deviation. Color version available online.

lactose addition, lactose is not presently thought to be an important ceramic MF membrane foulant. The effect of lactose on LF is considered to be due exclusively to its effect on viscosity.

\section{SP Removal}

The SP removal factor describes the ease by which $\mathrm{SP}$ passes through the membrane; a factor of 1 indicates that no SP is rejected. No differences in SP removal factor were detected $(P>0.05)$ among feeds at the initial flux. Mean SP removal factors for skim, MPC, and $\mathrm{MPC}+\mathrm{L}$ at the initial flux were 0.91, 0.96, and 0.97 , respectively. As skim and $\mathrm{MPC}+\mathrm{L}$ fluxes were increased from $55 \mathrm{~kg} \cdot \mathrm{m}^{-2} \cdot \mathrm{h}^{-1}$ to the $\mathrm{LF}$, SP removal factors decreased $(P=0.08,0.03$, respectively) due to fouling (Figure 5). The MPC SP removal factor did not change $(P>0.10)$ between $55 \mathrm{~kg} \cdot \mathrm{m}^{-2} \cdot \mathrm{h}^{-1}$ and the LF (Figure 5). However, further increases in TMP beyond the MPC LF would be expected to enhance fouling and reduce SP passage, as was evidenced by the decline in flux between 150 and $250 \mathrm{kPa}$ (Figure 2). Serum protein removal factors depicted in Figure 5 appear to indicate that the MPC and $\mathrm{MPC}+\mathrm{L}$ treatments passed more SP than the skim milk treatment. However, it should be reiterated that only TP (not SP) was determined by Kjeldahl for permeates and the MPC and MPC $+\mathrm{L}$ permeates contained more soluble $\mathrm{CN}$ than the skim milk permeate. The present study's assumption that all permeate TP was SP was based on previous MF work (Hurt et al., 2010, 2015a) in which CN only accounted for between 3 and $5 \%$ of the permeate TP. However, because the MF studies on which this assumption was based only involved skim milk (not MPC), this assumption is invalid for the present study. When SP removal factors were corrected for soluble $\mathrm{CN}$ in the permeates using SDS-PAGE data (Table 6) [i.e., permeate $\mathrm{SP}=$ permeate $\mathrm{TP} \times(100-\mathrm{CN}) / 100]$, SP removal factors were similar (0.87) for all feeds below the LF (data not shown). This indicates that below the LF, Ca does not cause a reduction in SP passage when using ceramic MF membranes under the conditions studied.

Manufacturers wishing to maximize processing efficiency should operate at as high of a flux as is maintainable without affecting separation efficiency. No differences in SP removal factor were observed between the initial and penultimate flux steps $(P>0.05)$. Our experience (Hurt et al., 2015b) with the GP membranes has demonstrated that it is best to operate at a $\mathrm{TMP}_{\text {avg }}$ below $150 \mathrm{kPa}$ (at approximately $85 \%$ of the LF) to reduce the likelihood of rapid fouling.

\section{CONCLUSIONS}

Skim milk, MPC, and MPC+L were each microfiltered at $50^{\circ} \mathrm{C}$ using $0.1-\mu \mathrm{m}$ GP ceramic MF membranes and flux was increased from $55 \mathrm{~kg} \cdot \mathrm{m}^{-2} \cdot \mathrm{h}^{-1}$ to the $\mathrm{LF}$. The LF of the skim, MPC, and MPC+L were 91,137 , and $124 \mathrm{~kg} \cdot \mathrm{m}^{-2} \cdot \mathrm{h}^{-1}$, respectively, at an average retentate protein concentration of $8.77 \%$. The difference in LF between skim milk and MPC+L was associated with a reduction in soluble $\mathrm{Ca}$. The difference in $\mathrm{LF}$ between the MPC and MPC+L was due to the higher viscosity contributed by lactose, but lactose was not thought to contribute to the foulant layer. No differences in SP rejection were detected among the 3 feeds below the LF. However, less SP passed through the membrane as fluxes approached the LF. Feeding the MF with MPC instead of skim milk produced a higher $\mathrm{LF}$ and a permeate with more TP due to an increase in soluble $\mathrm{CN}$ caused by micelle dissociation.

\section{ACKNOWLEDGMENTS}

The authors thank the New York State Milk Promotion Board (Albany, NY) and Northeast Dairy Foods Research Center (Ithaca, NY) for partial funding of this research. The generous donations of skim milk and MPC85 (OATKA Milk Products Cooperative Inc., Batavia, NY) and lactose monohydrate (Hilmar Cheese Company, Hilmar, CA) were invaluable to the success of this project. The technical assistance of Michelle Bilotta, Sara Bova, Chassidy Coon, Rachel Evanowski, and Nicole Martin from the Department of Food Sci- 
ence at Cornell University and Fernando Muñoz from Daisy Brand (Garland, TX) was greatly appreciated.

\section{REFERENCES}

Adams, M. C., and D. M. Barbano. 2013. Serum protein removal from skim milk with a 3 -stage, $3 \times$ ceramic Isoflux membrane process at $50^{\circ}$ C. J. Dairy Sci. 96:2020-2034.

AOAC International. 2000. Official Methods of Analysis. 17th ed. AOAC Int., Gaithersburg, MD.

Bacchin, P., P. Aimar, and R. W. Field. 2006. Critical and sustainable fluxes: Theory, experiments, and applications. J. Membr. Sci. 281:42-69.

Beliciu, C. M., and C. I. Moraru. 2009. Effect of solvent and temperature on the size distribution of casein micelles measured by dynamic light scattering. J. Dairy Sci. 92:1829-1839.

Brans, G., C. G. P. H. Schroen, R. G. M. van der Sman, and R. M. Boom. 2004. Membrane fractionation of milk: State of the art and challenges. J. Membr. Sci. 243:263-272.

Brew, K., and J. A. Grobler. 1992. Functional aspects of metal binding. Pages 207-217 in a Lactalbumin. Advanced Dairy Chemistry Volume 1: Proteins. P. F. Fox ed. Blackie \& Son Ltd., London, UK.

Davies, D. T., and A. J. R. Law. 1983. Variation in the protein composition of bovine casein micelles and serum casein in relation to micellar size and milk temperature. J. Dairy Res. 50:67-75.

Elwell, M. W., and D. M. Barbano. 2006. Use of microfiltration to improve fluid milk quality. J. Dairy Sci. 89:E20-E30.

Fernandez-Martin, F. 1972. Influence of temperature and composition on some physical properties of milk and milk concentrates II: Viscosity. J. Dairy Res. 39:75-82

Fox, P. F., and P. L. H. McSweeney. 1998. Composition of milk salts. Pages 240-241 in Salts of Milk. Dairy Chemistry and Biochemistry. Blackie Academic \& Professional, London, UK.

Garcera, R. M., and E. Toujas, inventors. 2002. Graded permeability macroporous support for crossflow filtration. Societe de Ceramiques Techniques, assignee. US Pat. No. 6,375,014 B1.

Hanemaaijer, J. H., T. Robbertsen, T. van den Boomgaard, and J. W. Gunnink. 1989. Fouling of ultrafiltration membranes-The role of protein adsorption and salt precipitation. J. Membr. Sci. 40:199-217.

Holt, C., D. T. Davies, and A. J. R. Law. 1986. Effects of colloidal calcium phosphate content and free calcium ion concentration in the milk serum on the dissociation of bovine casein micelles. J. Dairy Res. 53:557-572.

Hurt, E., J. Zulewska, M. Newbold, and D. M. Barbano. 2010. Micellar casein concentrate production with a $3 \mathrm{X}, 3$-stage uniform transmembrane pressure ceramic membrane process at $50^{\circ} \mathrm{C}$. J. Dairy Sci. 93:5588-5600

Hurt, E. E., M. C. Adams, and D. M. Barbano. 2015a. Microfiltration of skim milk and modified skim milk using a $0.1 \mu \mathrm{m}$ ceramic uniform transmembrane pressure system at temperatures of 50, 55, 60 and $65^{\circ} \mathrm{C}$. J. Dairy Sci. 98:765-780.

Hurt, E. E., M. C. Adams, and D. M. Barbano. 2015b. Microfiltration: Impact of retentate protein concentration on limiting flux and serum protein removal with $4 \mathrm{~mm}$ channel ceramic microfiltration membranes. J. Dairy Sci. 98:2234-2244.

Hurt, E. E., and D. M. Barbano. 2015. Factors that influence the membrane area of a multi-stage microfiltration process required to produce a micellar casein concentrate. J. Dairy Sci. 98:2222-2233.

Jimenez-Lopez, A. J. E., N. Leconte, O. Dehainault, C. Geneste, L. Fromont, and G. Gesan-Guiziou. 2008. Role of milk constituents on critical conditions and deposit structure in skim milk microfiltration $(0.1 \mu \mathrm{m})$. Separ. Purif. Tech. 61:33-43.

Karleskind, D., I. Laye, F. I. Mei, and C. V. Morr. 1995. Chemical pretreatment and microfiltration for making delipidized whey protein concentrate. J. Food Sci. 60:221-226.
Kaylegian, K. E., G. E. Houghton, J. M. Lynch, J. R. Fleming, and D. M. Barbano. 2006. Calibration of infrared milk analyzers: Modified milk versus producer milk. J. Dairy Sci. 89:2817-2832.

Lynch, J. M., D. M. Barbano, and J. R. Fleming. 2007. Determination of the lactose content of fluid milk by spectrophotometric enzymatic analysis using weight additions and path length adjustment: Collaborative study. J. AOAC Int. 90:196-216.

Lynch, J. M., D. M. Barbano, M. Schweisthal, and J. R. Fleming. 2006. Precalibration evaluation procedures for mid-infrared milk analyzers. J. Dairy Sci. 89:2761-2774.

Marshall, A. D., and G. Daufin. 1995. Physico-chemical aspects of membrane fouling by dairy fluids. Fouling and Cleaning in Pressure Driven Membrane Processes. International Dairy Federation Bulletin 9504. Brussels, Belgium.

Morison, K. R., and F. M. Mackay. 2001. Viscosity of lactose and whey protein solutions. Int. J. Food Prop. 4:441-454

Morr, C. V. 1973. Milk ultracentrifugal opalescent layer 1: Composition as influenced by heat, temperature, and $\mathrm{pH}$. J. Dairy Sci. $56: 544-552$.

Piry, A., A. Heino, W. Kuhnl, T. Grein, S. Ripperger, and U. Kulozik. 2012. Effect of membrane length, membrane resistance, and filtration conditions on the fractionation of milk proteins by microfiltration. J. Dairy Sci. 95:1590-1602.

Pouliot, Y., M. Boulet, and P. Paquin. 1989. An experimental technique for the study of milk salt balance. J. Dairy Sci. 72:36-40.

Rao, H. G. R., M. J. Lewis, and A. S. Grandison. 1994. Effect of soluble calcium of milk on fouling of ultrafiltration membranes. J. Sci. Food Agric. 65:249-256.

Rice, G., A. Barber, A. O'Conner, G. Stevens, and S. Kentish. 2009. Fouling of NF membranes by dairy ultrafiltration permeates. J. Membr. Sci. 330:117-126.

Samuelsson, G., P. Dejmek, G. Tragardh, and M. Paulsson. 1997a. Minimizing whey protein retention in cross-flow microfiltration of skim milk. Int. Dairy J. 7:237-242.

Samuelsson, G., I. H. Huisman, G. Tragardh, and M. Paulsson. 1997b. Predicting limiting flux of skim milk in crossflow microfiltration. J. Membr. Sci. 129:277-281

Sauer, A., and C. Moraru. 2012. Heat stability of micellar casein concentrates as affected by temperature and $\mathrm{pH}$. J. Dairy Sci. 95:6339-6350.

Tan, T. J., D. Wang, and C. I. Moraru. 2014. A physiochemical investigation of membrane fouling in cold microfiltration of skim milk. J. Dairy Sci. 97:4759-4771.

Tang, Q., P. A. Munro, and O. J. McCarthy. 1993. Rheology of whey protein concentrate solutions as a function of concentrations, temperature, pH, and salt concentration. J. Dairy Res. 60:349-361.

Vetier, C., M. Bennasar, and B. T. de la Fuente. 1988. Study of the fouling of a mineral microfiltration membrane using scanning electron microscopy and physicochemical analyses in the processing of milk. J. Dairy Res. 55:381-400.

Walstra, P., J. T. M. Wouters, and T. J. Geurts. 2006. Composition and structure. Page 8 in Milk: Main Characteristics. Dairy Science and Technology. 2nd ed. Taylor \& Francis Group. Boca Raton, FL.

Weast, R. C., M. J. Astle, and W. H. Beyer. 1988. CRC Handbook of Chemistry and Physics. 69th ed. CRC Press Inc., Boca Raton, FL.

Weissberger, A., and B. Rossiter. 1971. Physical Methods of Chemistry Vol. 1, Techniques of Chemistry Part IV. Wiley InterScience, New York, NY.

Wojciechowski, K. L., and D. M. Barbano. 2015. Modification of the Kjeldahl noncasein nitrogen method to include bovine milk concentrates and milk from other species. J. Dairy Sci. 98:7510-7526.

Zulewska, J., and D. M. Barbano. 2013. Influence of casein on flux and passage of serum proteins during microfiltration using polymeric spiral-wound membranes at 50 C. J. Dairy Sci. 96:2048-2060.

Zulewska, J., M. Newbold, and D. M. Barbano. 2009. Efficiency of serum protein removal from skim milk with ceramic and polymeric membranes at $50^{\circ}$ C. J. Dairy Sci. 92:1361-1377. 